\title{
Sex vs Gender: An unanswered paradox
}

\author{
Bobbi M. Woodhill \\ University of New England, Armidale, Australia; \\ Dr. Curtis A. Samuels \\ University of California, Berkeley.
}

\section{INTRODUCTION}

It is widely accepted that gender identity results from the interaction between structural genotypes, functional phenotypes, and interaction with the social environment (Uribe et al., 2020; Fernandez et al., 2020; Rippon, 2019; Fine et al., 2017). For all academic intents and purposes, sex-linked differences in behavior are either a mosaic available equally (Joel et al., 2015), or any differences are merely a few and of moderate strength (Zell et al., 2015). This paper is another visitation on the seemingly un-killable debate about sexlinked differences, or the 'Whac-a-Mole' effect; where a problem keeps recurring after it is supposedly fixed (Rippon, 2019, p. xii).

\section{AIM}

It is our view the debate on identity development can be progressed by bringing back into focus specific innate-based differences steeped in the competencies that match reproductive roles as opposed to general cognitive skills. Additionally, our understanding is that the similarities hypothesis of a sex/gender mosaic (see later) accounts for behavior that are 'for the most part' insignificant and so does not account for all human behavior. This led us to focus and explore what are the behavioral differences are not insignificantnamely those 'few behaviors' (Hyde et al., 2018; Hyde, 2005), and 'some neural and behavioral endpoints' (Fine et al., 2017) with moderate to large differences (Zell et al., 2015). 3 NEW RESEARCH

Recent theories have argued there is no natural dichotomy of gendered behavior and propose the notional merging of otherwise distinct categories for sex and gender into a mosaic of sex/gender (Rippon, 2019; Joel \& McCarthy, 2017; Joel et al., 2015; Rippon et al., 2014). Their arguments favor we desist labelling sex and gender as separate variables and combine them into the singular term - 'sex/gender' (Fine et al., 2019; Joel et al., 2015; Kaiser, 2012), or 'gender/sex' (van Anders, 2015). Furthermore, sex-linked differences in behavior have been presented as more socioenvironmental than biological in origin (Fine et al., 2017), and for the most part insignificant (Eliot et al., 2021).

\subsection{Old problems}

The problems with 'difference' research have been well documented. Confounding results have been attributed to inconsistent definitions and methodology; categories vs. dimensions, fixed vs. flexible difference, false 
positives, small sample size, small effect size, absence of studies reporting null findings, and animal comparisons to humans (Fine, 2020; Hyde, 2005).

The lack of attention to these issues may have affected results more prominently. Additionally 'neurosexism' has become an 'item.' Neurosexism is where studies assume stereotyped differences of old and focus on finding them with new technology (Fine, 2013). In the modern Anthropocene, this may reflect an excess significance bias in fMRI studies of human brain in evaluating sex-linked differences (David et al., 2018).

Despite any neurosexism, invalid studies, small sample sizes, research bias, under-reported negative studies (the file drawer problem) amongst the mosaic of the sex differences found in the central nervous system, around ten can be linked to sex differences in behavior (Zell et al., 2015).

\section{NON-ESSENTIALISM}

It was Simone De Beauvoir who saw the body as embodied in its situations in the world, and so subject to socioenvironmental influences. It is now widely accepted that the relationship between the brain and its environment is a twoway street.

A recent a debate on sex/gender differences, or rather the absence of the same, makes a valid conclusion that the hundreds of studies reviewed fall prey to being underpowered and or unreplicated. The authors conclude the human brain is not sexually dimorphic either structurally (accounting for overall size) or functionally. Yet there is also a paradox in the statement that differences are insignificant "except for a few behaviors" (Eliot et al. $(2021$, p. 6), for example in aggression. The very fact that differences in aggression levels are widely agreed upon ipso facto refutes the claim there are no gender differences. Of these 'few behaviors' (Eliot et al. (2021; Hyde et al., 2018; Hyde, 2005), and differences in 'some neural and behavioral endpoints' (Fine et al., 2017), it is unknown precisely "what advantage the dimorphism [if any] gives males and females in terms of function" (McCarthy et al., 2017, p. 24).

\section{EVOLUTION}

In this paper we are not discussing why did sex evolve or why there are only two sexes (Parker (2021), however, it is noteworthy that we are a sexually reproducing species where sexual behavior [physical and cognitive] is a subset of reproduction (van der Dennen, 2005). And "Sex differences in behavior are ubiquitous among sexually reproducing species and presumably contribute in some way to the reproductive success of the organism" (McCarthy et al., 2017 , p. 5). For the good of their kind, sexually reproducing species are best suited to incorporate beneficial genetic mutations, exclude deleterious mutations, and keep up with environmental change (van der Dennen, 2005).

Our review will focus on the asymmetry of behavior from a somewhat evolutionary perspective. Importantly,

An evolutionary view of sex differences in behavior is not a relapse into the obsolete and acrimonious nature-versus-nurture debate. Instead, it provides a general framework to understand them as consequences of different reproductive and parental investment strategies. 
(van der Dennen, 2005).

Overall, everything genetic may be differentially expressed according to socioenvironmental conditions.

While two sexes and two genders have been unproblematic in the fabric of everyday life, at least for those who conform. the notion of 'a gendered self' only seems explicable philosophically. Indeed, it is generally agreed our sense of maleness or femaleness resides in the brain (Legato, 2018; Bao \& Swaab, 2011). Nonetheless, "the factors that create the gendered brain and gender identity are not yet clearly defined" (Legato, 2018, p. 65).

\section{Terminology}

From scientific to lay communities, definitions of 'sex' and 'gender' remain confusing and divisive.

\subsection{Sex}

We are a sexually reproducing species, and much like the necessity to attain a patient's sex on admission to a hospital emergency department, this article will keep 'sex' as initially defined by Unger (1979) - the body's obvious physical and reproductive anatomy only.

\subsection{Gender}

This article maintains the separation of bodily sex separate from brain sex (gender). According to the American Psychological Association (APA), gender identity is a person's deeply-felt, inherent sense of being a boy, a man, or a male; a girl, a woman, or a female, or an alternative gender, e.g., queer, non-binary). Gender in this current work is not used as a term for social expectations or social roles.

\subsection{Dimorphic}

The term 'dimorphic,' meaning occurring in two distinct forms, is used in this article to describe significant differences with some overlap (McCarthy \& Konkle, 2005).

\subsection{Canalized}

Most species maintain abundant genetic variation and experience a range of environmental conditions, yet phenotypic variation is low. That is, development is robust to changes in genotype and environment. It has been claimed that this robustness, termed canalization, evolves because of long-term natural selection for optimal phenotypes.

(Siegal \& Bergman, 2002, p. 10528).

In this review, canalized psycho-neuroanatomy refers to that which is moderately focused on male and female endpoints depicting sex differences, i.e., psycho-neuroanatomy is canalized, or "weakly bimodal" (Joel \& McCarthy, 2017, p. 381).

\section{NEW-AGE RESEARCH}

New-age research presents sex / gender as a mosaic (Joel \& McCarthy, 2017; Rippon et al, 2014) and calls for us to move away from dimorphic thinking (Eliot et al., 2021). This paper focuses on universal sex differences in the 
' $f e w$ ' behaviors unrelated to outside (socioenvironmental) influences and away from many behaviors widely accepted as mosaic under the sex / gender banner.

How is it the genetic and hormonal components of bodily sex create two distinctly different reproductive systems - and yet human male and female behavior shows itself to be flexible and surprisingly similar?

(Fine, 2020, p. 1)

Here again we find an implicit reference to difference in the phrase 'male and female behavior shows itself to be flexible and surprisingly similar', as opposed to exactly the same. Considering we have heteromorphic sex chromosomes, and only females endure the processes of ovulation, pregnancy, and lactation, we can reasonably ask why wouldn't there be differences in innate cognitions relative to the differences in the reproduction burden? Our astounding physical differences firmly suggest the probability of cognitive differences, and this question can be asked another way:

...it would be highly negligent of evolution [or Nature, or God] to create a sexually dimorphic species without at the same time 'programming' or 'wiring,' or otherwise preparing the individuals for the divergent strategies, functions, and roles they have to play during their lifetimes, especially in the reproductive domain...

(van der Dennen, 2005, p., 2).

Theoretically, the notion of human behavioral overlap or mosaic removes the need to separate sex and gender. However, the idea that prenatal brains belong to a single heterogeneous population is an enormous ambition, according to Pavlova (2017).

\subsection{Congruent Development}

The brain's high function areas have been labelled initially intersex and not dimorphic (Hyde et al., 2018). However, around the time of birth, the sex steroid hormones have exerted some permanent changes in the CNS (Hines, 2020; Zuloaga et al., 2009).

Even if other factors such as culture and environment influence gender identity development, evidence from individuals with intersex conditions suggests the critical role of prenatal androgen exposure in sex differentiation of the brain.

(Ristori et al., 2020, p. 4).

The presence of genes ( $\mathrm{X}$ or $\mathrm{Y}$ ) precedes gonad development and gonads secrete sex steroid hormones. In the absence of an SRY gene on a Y chromosome, the embryo's bipotential primordial genital structures develop into female internal and external reproductive organs (Tasopoulos, 2018). The dominance of testosterone from around birth ensures masculinization of fetal gonads (Zuloaga et al., 2009; Wizemann \& Pardue, 2001). No matter which is considered the default state for human embryos, male or female (Joel et al., 2020), gonad formation precedes neural tube development (see also the trans community later).

Professional and non-professional articles continue to present gender as a person's sense-of-self within several intersecting factors and influences (Fiani, 2018; Strauss et al., 2017), however, no one has ventured to suggest what the 
'factors' that make gender are, nor from where they might originate. We have extracted what we believe are significant and stable sex differences.

\section{A FEW SIGNIFICANT STABLE SEX DIFFERENCES}

Though the 'characteristics' of 'sex-related behavior' relative to the physicality of reproduction are connected to the presence of ova or testes and accepted as dimorphic, sex-related cognitive behaviors have not been explicitly identified. Some see gender as 'subconscious sex' and an intrinsic part of an individual that hardwires traits of one sex or the other into the brain (Serano, 2016). But again, these 'traits' are not clarified. While there appears to be "...much more overlap in the behavioral phenotypes of males and females especially outside the context of reproduction" (McCarthy et al., 2017 , p. 24), apart from physical behaviors related to mating, any attempt to extrapolate these 'behaviors' and 'traits' is missing in the literature.

Paradoxical questions remain.

\subsection{Paradoxes}

Which part of genotype, functional phenotype, and the social environment plays a core role in determining neural and behavioral outcomes, including gendered behavior? Does living in a society beget behavioral norms, which, over evolutionary time, beget stable neurology? Or does stable neurology related to reproduction beget appropriate behavior? Margaret Mead was once criticized for wanting it both ways.

Until the 21st century,

...it has been challenging to speculate on biological, evolutionary, or

psychosocial reasons driving [sex-linked] differences.

(Reber \& Tranel, 2017, p. 275).

The paradoxes were examined at length by Fine et al. (2017) who surmised sex-linked patterns of behavior, including differences, are perhaps better explained in terms of the inheritance of socioenvironmental conditions across generations. The authors present "genetic material is not the only stable inherited resource for development" (p. 668) and that adaptive development can be contingent on specific environmental resources. Even at the level of parent-child attachment, various styles likely evolved as context-appropriate adaptations that helped children survive in the world (El-Kalliny \& Donaldson, 2021).

Another way of viewing the bio-psycho-social model suggests that behavior is mediated by the brain and the brain and hormones are subserved by behavior (Owen-Blakemore et al., 2009). That is, both cause is consequential and consequence is causal.

The socioenvironmental model of evolution does not say there are no sexlinked differences, but that they are "sometimes better explained in terms of inherited socioenvironmental conditions" (Fine et al., 2017, p. 666). In other words they possibly emanate from social pressures more than biological pressures. 
Society begets behavioral norms which, over periods of evolutionary time, consistent environmental influence begets stable neurology (Fine et al., 2017), ad infinitum. In contrast, we think it still reasonable to propose genetics is responsible for evolution of some sex-linked cognitive traits relative to reproduction, all the while under the influence of socio-cultural norms.

Whichever way you view development, it does not matter to a theory of an anatomical location for gender. We would like to suggest that whether reproductive strategies are socially, biologically, or biopsychosocially driven, there is another interpretation available - evolved adaptive biology must reside somewhere anatomically. The ' $\mathrm{eew}$ ' behavioral differences that kept resurfacing in our review must emanate from somewhere biologically.

In this paper we are not so much debating the evolutionary source of sexlinked differences, merely their existence and what this means to notions of gender identity. Furthermore, evolutionary time frames are irrelevant to an individual life time. It doesn't matter which way round you view development, the expression of behavior is biologically driven and behavior relevant to reproduction is not likely to change in an individual life time and arguably never if mother Nature is to have its way in continuing the human species.

Although still the topic of much debate, small to moderate gender differences show stable and substantial differences in more than a few areas. Studies clearly demonstrate that genetic and hormonal components of sex can affect the structure and function of brain cells in utero and throughout life (Fine et al., 2017). Furthermore, considering differences are also likely context dependent across domains (Del Giudice et al., 2012), small gender differences should not be regarded as trivial (Zell et al., 2015). Likewise, a 'small' effect size does not equal a trivial effect (Sanchis-Segura et al., 2019).

Proposed sex differences in the brain (structural and functional) have historically been attributed to the combined effects of hormones, genes, epigenetics, and the social environment (Feldman \& Lindquist, 2021; Ratnu et al., 2017; Fine et al., 2017; Eagly \& Wood, 2013). Biology and culture seemingly work hand in hand (Joel et al., 2020; Fine et. al., 2019).

Furthermore, neural plasticity reveals a sustained neural activity can change the brain (Doidge, 2008). Areas of the brain associated with particular skills can be shown to increase in size with training and subsequent acquisition of the skill (Rippon, 2019). However, we are "a very long way off modelling any kind of causal relationship" (Rippon, 2019, p. 21).

Are there any and what would any universal, stable, significant sex-linked differences mean? This article focusses on sex, gender, and cognitions most relevant to reproduction comprising the reproductive axis (RA). Any dimorphism should not be unsurprising in a sexually reproducing and social mammalian species. We will suggest the sense of early uninfluenced (lifenaive) gendered self has evolved over millions of years of selection processes and is related in part to cognitive dimorphic behaviors under the influence of neural networks in the reproductive axis (RA). 


\subsection{Reproductive Axis}

Under a broad umbrella, the RA can be considered as consisting of any organ in the associated networks of neurons targeted by sex steroids. Following a review of the differences in neural and endocrine development, differences in the reproductive burden on ciswomen compared to cismen, and research into the trans community, we present a case for the physical location of an internal and perceptual sense or feeling of gender associated with the RA and the cognitive behaviors differentially linked with reproduction throughout the lifespan.

To associate gender with the RA, the RA and its regions must be dimorphic and canalized towards female and male endpoints of a spectrum, as are, for example, sexual orientation (Savin-Williams, 2016) and intersex conditions (García-Acero et al., 2020). If specific brain regions are essential to specific cognitions, and these regions are dimorphic, it is reasonable to suggest the associated behaviors are likely dimorphic.

The reproduction axis stems from the testes, ovaries, and on to the limbic system. The Limbic system is one section of the survival or instinctual brain as opposed to the thinking brain. The survival brain also includes the cerebellum and brain stem (Stanley, 2019). The main components of the limbic system are the hippocampus, the amygdala, and the hypothalamus (Roxo et al., 2011). Traditionally the RA consists of five main components: the extra-hypothalamic central nervous system (CNS), pituitary, testis, ovaries (Acevedo-Rodriguez et al., 2018; Pejić et al., 2015; Klein et al., 1994), which are all target organs of sex steroid hormones (Ruiz-Cortes, 2012; Wierman, 2007). As we suggested, the RA can be considered as consisting of any organ in the associated networks of neurons targeted by sex steroids.

The RA is a tightly regulated feedback loop paramount to reproductive potential (Acevedo-Rodriguez et al., 2018; Couse et al., 2003; Klein et al., 1994). Control of the RA occurs at all levels. It is crucial for female reproduction, where neuroendocrine control lays with gonadotropin-releasing hormone $(\mathrm{GnRH})$ neurons dispersed from the hypothalamic region of the limbic system (Alzahrani et al., 2019; Acevedo-Rodriguez et al., 2018). Increases in GnRH are required for a luteinizing hormone (LH) surge and, consequently, ovulation (Acevedo-Rodriguez et al., 2018). The RA further coordinates the production and secretion of the gonadotropins, including luteinizing hormone ( $\mathrm{LH}$ ) and follicle-stimulating hormone (FSH) from the anterior pituitary, which in turn stimulates the release of the sex steroids, androgens, estrogens, and progesterone produced primarily by the ovary, corpus luteum, and adrenals (Blair et al., 2015).

Regulation of reproductive circuitry in the brain includes kisspeptin neurons. Acevedo-Rodriguez et al. (2018) report kisspeptin detection primarily in two regions of the hypothalamus and preoptic area. It is an important hormone that starts the release of several other hormones. Kiss1 gene expression is more generous in females than males who do not show a LH surge (Acevedo-Rodriguez et al., 2018). Estrogen and androgen receptors show high distribution levels in the pituitary, hypothalamus, amygdala, putamen, ovaries, testes, and uterus (Denley., 2018; Swaab, 2004; Sato et al., 2004; McEwen, 2001); in other words, in the reproductive axis overall. 
In line with locating biological gender in uninfluenced (life-naive) and in utero, one such study (gestational age 25-39 weeks), reported differences between male and female fetuses in FC within and between seven neural networks, namely, between cortical and sub-cortical regions and specifically between the prefrontal cortex (PFC), superior frontal gyrus (SFG), and visual cortex. The authors claim this as evidence development of regions of the fetal brain varies by sex which likely acts as precursor to life-long differences in neural relays (Wheelock et al., 2019). The prefrontal cortex is liberally associated with many parts of the brain, notably cortical regions and limbic and midbrain structures involved in affect, memory, and reward (Fuster, 2009).

The putamen, thalamus, hippocampus, hypothalamus, and amygdala are repeatedly shown to be dimorphic in post-mortem and in-vivo imaging studies (Lotze et al., 2019; Goldstein et al., 2001). Though these studies are not replicated elsewhere, the two subcortical regions that differ across various studies are the putamen and amygdala (Eliot et al., 2021).

We consider the cortex and all its subsystems in the limbic region - putamen, hippocampus, amygdala, and hypothalamus - as parts of the RA. Studies based on large samples reveal, with moderate significance $(d=0.18)$, somewhat consistent different volumes for two subcortical structures: the amygdala and putamen (Lotze et al., 2019). The strength of association between sensorimotor, visual, and some prefrontal areas is overall higher in males (Ritchie et al., 2018), although absolute difference in amygdala volume was not statistically significant in another large $(N=872)$ meta-analysis (Marwha et al., 2017).

With a focus on evolutionary selection pressures benefiting both self and offspring, we think it reasonable to suggest behavior especially relevant to reproduction and care of offspring (see later) are particularly significant.

\subsection{Reproductive Behavior}

Recent consistent findings with different samples point to the most significant and most stable gender differences occurring in several areas, both in sickness (Salk et al., 2017; Loomes et al., 2017) and in health (Zell et al., 2015; Hyde, 2005).

Evolutionary pressures make behavior selection more obvious. There are sex differences in consequent behavior, with men showing more 'fight-or flight' and women showing more 'tend-and-befriend' (Verma et al., 2011), both responses subject to intense evolutionary pressures (Vogt, 2017; Taylor et al., 2000). Fight (aggression) typically characterizes men's behavior under stress, and women's by tend [and befriend] or flight (social withdrawal, substance abuse). This difference may demonstrate how emotional expression for males and females may recruit different cerebral networks (Kret \& De Gelder, 2012). Additionally, the ongoing sexual division of labor highlights how males and females may employ their innate abilities to procure resources and achieve cooperation in the care of offspring while also under the influence of socialization and culture (Tay et al., 2019).

A meta-synthesis of over 20,000 studies provided data from a large subject pool. As we mentioned, the 'few [moderately significant] differences' so often 
glossed over in other research amount to mental rotation ability, interest in people vs. things, socio-emotional skills, response to noxious stimulation, visually induced fear, peer attachment, confidence in physicality, and aggression (Zell et al., 2015).

In answering what particular evolutionarily / socially purpose these differentials concur, we think it reasonable to suggest the two behavioral areas of aggression and empathy demonstrate behavior especially relevant to reproduction. The dimorphic RA incorporates the brain areas processing cognitions related to reproduction, in other words, we view these cognitions relating to care of offspring, i.e., parenting, as gendered and may be reinforced or not by outside factors such as culture and social learning.

\section{Parenting}

Greater than trivial behavior differences have been presented in the arenas of aggression and sexuality (Hyde et al., 2018), courtship, and care of offspring (Meyer-Bahlburg, 2019).

Supporting the similarities hypotheses and in terms of statistical effect size, many differences are small $(d=0.20)$ to moderate $(d=0.50)$ (Hyde, 2005, 2014) with distributions on most variables overlapping by around $85 \%$ (Zell et al., 2015; Cohen, 1988). The moderate to large gender differences highlighted above are notable exceptions to the similarities hypothesis on sex differences with specific bearing to this work.

Human females and males of all ages and reproductive conditions can express infant-caregiving behavior (Saltzman \& Maestripieri, 2011). Further, cognitions are the source of the emotional states and individual traits during pre- and postpartum mothering (Lonstein et al., 2014). Nonetheless, the levels of estrogen, progesterone, prolactin, oxytocin, and testosterone (T) present in a parent influence variation in parental behavior both within and between individuals (Saltzman \& Maestripieri, 2011).

The different mix of hormones between males and females throughout the lifespan thus becomes relevant to parenting behavior. As Vigil (2009) suggests, "Perhaps the gender-dependent correlates of neural activity reflect neural predispositions in mothers for responses to preverbal infant vocalizations" (p. 402).

Under the broader neo-analytic understanding gained from the feminist theory of Nancy Chodorow, we may view sexuality concerning reproduction as a universal and enduring element of the sexual division of [reproduction] (Chodorow, 1999).

\subsection{Physical sexuality}

Reproductive sexuality is an "indirect consequence" of prenatal sex steroids that, in turn, affect the developing brain to promote sexual behavior where androphilic men and gynephilic women predominate (Bailey et al., 2016, p. 69).

The existence of androphilic males and gynephilic females clarifies that sexual orientation is more dependent on the irreversible effects of early hormones (Bailey et al., 2016). The early effect does not negate Freud's understanding 
of sexuality as primarily about bonding ahead of reproduction (Freud, 1966). Sigmund Freud was the first to elaborate on the primary function of sexual bonding as the path to intimacy and its secondary purpose as procreation (Freud, 1966). This elaboration is unsurprising in light of the socioenvironmental view of evolution (Fine et al., 2017) and the role of temporal developmental of bodily sex (sex) and brain sex (gender) in the trans community discussed later.

Mothering and fathering are tethered to courtship that is tethered to mating behavior, which is, in turn, is tethered to the environment and care of dependent offspring. As such, this broader sexuality is relative to reproductive roles, as others have both suggested (Pfaff, 2011; Owen-Blakemore et al., 2009; Bartky, 1999; Buss, 1995, 2009) and implied (Reber \& Tranel, 2017).

Nevertheless, the physicality of mating per se is not the topic of this article, whereas care of offspring is.

\subsection{Care of offspring}

The main drive of evolution is to perpetrate a species (Rutherford, 2018). Behaviors across mammalian species directed toward young offspring's care exhibit striking sex differences (Numan \& Insel, 2006). If animal studies are useful, and it seems they can be (Guillamon et al., 2016; van der Dennen, 2005), juvenile sex-typed play, physical aggression, parenting behavior, and maze performance differ between male and female rats (Hines, 2020). Caregiving by most animals, including humans, is highly sexually dimorphic, provided by mothers, and supported by fathers. Arguably the most powerful influences on how mothers mother and fathers father comes from their innate biology combined with their own experiences growing up during infant reinforcement or diminishing; these processes surely serve an important evolutionary role. "Sex typical emotive behaviors would have coevolved to regulate interpersonal dynamics and enhance social fitness" (Vigil, 2009, p. 376).

Empathy is a fundamental emotion in infant nurturance and caregiving (Grabowska, 2017; Swain et al., 2007). The evidence for female advantage in emotional perception and expression (e.g., recognizing emotions from facial displays) and non-verbal behavior such as smiling and gesturing is consistent (Schulte-Ruther et al., 2008), and the relevance of such an advantage to reproduction and care of offspring is unmistakable.

Behaviors related to reproduction are recognizable in both parents in the levels of responses such as sociability, attachment, sentimentality (Stam, Huang, \& Van den Stock, 2019), aggression (Zell et al., 2015), in defend or befriend (Hoekzema et al., 2015; Sokolowski \& Corbin, 2012; McCarthy et al., 2012; Pearson et al., 2009; Zietsch et al., 2008), instinct (Sweatt et al., 2013), and significantly in empathy (Swain et al., 2007). Others have presented similar claims (see Kolla et al., 2021; Zaidi, 2010; Decety \& Lamm 2006).

Empathy is "especially relevant to parenting in which infant needs are great, yet most communication is exclusively non-verbal" (Swain et al., 2007, p. 23). Females exhibit elaborate maternal behaviors to ensure their offspring's survival across all mammalian species (Fang et al., 2018). Animal and human studies reveal that neural and endocrine systems likely account for the 
development and sensitivity of gendered parental behavior across the lifespan (Champagne \& Curley, 2016; Lonstein et al., 2014).

In humans the limbic system (the emotional nervous system), specifically the subcortical systems, including the amygdala, hypothalamus, and hippocampus, has been associated with emotional processing and motivation (Tunc et al., 2016; Hahn et al., 2015).

The limbic system zones develop differentially (Zaidi, 2010; Sakata \& Crews, 2004; Kruijver et al., 2000) and are stable across the lifespan (Simerly, 2010, 2002; McCarthy \& Konkle, 2005). Estrogen sensitivity within the MPOA governs mammalian maternal behavior and is stable across the lifespan (Champagne \& Curley, 2016).

Studies examining emotional differences between the sexes are many. The nondescript hackneyed cliché 'being emotional' likely has innate roots. The academic consensus is that both sexes experience emotion equally but differently; men show stronger emotionality to angry and negative stimuli while women are more expressive, especially with positive emotions, while internalizing negative ones (Deng et al., 2016; Chaplin, 2015). These differences remain clear in Facebook and Twitter posts of the modern era (Parkins, 2012).

We are not discussing causal origins of emotional difference per se, yet arguably, all behaviors related to reproduction and parenting are strongly associated with parenting roles and the RA, but especially empathy (below) and aggression (see 'Aggression by another name' later).

\subsection{Empathy}

Measures of fantasy, empathic concern, perspective taking, and personal distress with the Interpersonal Reactivity Index confirm the dimensionality of these human traits (Carothers \& Reis, 2013). Yet these dimensions are both well-acknowledged (Kreukels \& Guillamon, 2016) and contested (Eliot et al., 2021).

Intuitively, considering pregnancy and childbirth, the opportunity to express empathy is greater for females invested in their offspring. To borrow from Raz et al. (2014), does one tend to cry for, or with, another person in their time of need? In other words, do we merely understand another person is having a bad time of it, or do we feel it in ourselves in response to theirs (Stuijfzand et al., 2016), empathy being the latter? Also, is it the case growing from childhood through adolescence to adulthood that only culture teaches females to show more effective empathy than males?

The broad agreement on a definition of empathy says it comprises both affective (feeling similar emotions to another person) and cognitive components (understanding the feelings of another person) (Sindermann, Cooper, \& Montag, 2019). Empathy can also be defined as "appropriate perception, experience and response to another's emotion" (Swain et al., 2007, p. 23): It is "the ability to understand and share in the internal states of others" (Christov-Moore et al., 2014, p. 604) and "without confusion between oneself and others" (Decety \& Lamm, 2006, p. 146). 
As an ancient biological phenomenon, empathy has both evolutionary and developmental precursors as an instinct involved in the care of offspring. "Evolutionary biologists suggest that empathic helping behavior has evolved because of its contribution to genetic fitness" (Decety \& Lamm, 2006, p. 1146). The evolutionary value of empathy lies in its ability to evoke altruistic motivation to see and act toward reducing another's need (Batson et al., 1981).

The significance of empathy is its ability to identify and respond to another's mental state and in the care of offspring; it can respond to infant cues (Schulte-Ruther et al., 2008). Participants in the Batson et al. (1981) study above were all adult females. However, any difference between the sexes remains a hot topic of debate with "no agreement here on the existence of infant empathy in either sex... at least not until you are well into your second year" (Rippon, 2019, p. 192). Though there are undoubtedly sex differences in empathy in studies with older infants and children (see Auyeung et al., 2009).

A recent mixed study of children ( $N=93 ; 42$ girls) demonstrated the norm for empathy-related comforting develops somewhere between three to five years of age; and is more pronounced in five-year-olds, yet with three-year-olds showing more comforting as opposed to ignoring or laughing (Paulus et al., 2020). Furthermore, the results did demonstrated empathy in children is both an innate and acquired response, perhaps just not expressed under age three. Three-year-olds reported a gender difference, with girls preferring comforting to ignoring those in need (Paulus et al., 2020). In a small mixed group study not incorporating gender as a covariate, a small group $(N=16)$ of three-yearolds highlighted how self-initiated empathy appeared as an innate and implicit mode of behavior towards peers expressing pain, sadness, being unfairly treated, or losing self-esteem (Nergaard, 2019).

Childhood gaps in empathy levels appear to increase in adolescence: this could be because of the biological (Frere et al., 2020) and social changes at this time in development. In a moderately large study of $4-11$ year old's ( $N$ $=1256$ ) empathy and systematizing, $\mathrm{F}>\mathrm{M}$ on the empathy quotient and $\mathrm{M}>\mathrm{F}$ on the systemizing quotient. This result suggests different brain types are present at an early age (Auyeung et al., 2009). In a small study of 4-year-olds indicative of fetal testosterone effects on development, girls demonstrated a better quality of social relationships (Knickmeyer et al., 2005).

The social world of adolescent females encourages troubles talk and empathy, whereas adolescent males' social world emphasizes dominance, competition (Stuijfzand et al., 2016).

From a biological perspective, over time, $\mathrm{T}$ [and estrogen] levels can be considered a "trait[s]" (Smith et al., 2012, p. 12). T levels have been linked to a fall in empathy (Hermans et al., 2006; Cohen-Bendahan et al., 2005). A 4 9 fold increase in a girl's estrogen levels during puberty coincides with growth in hippocampal receptors (Goddings et al., 2014). Recall the hippocampus is a dimorphic sub-cortical region of the limbic system.

Concern for others guides women's moral compass, while men's can be more rules-based (Gilligan, 1993). This theory has been supported with findings confirming "typical females on average are more empathic, typical males on 
average are more systems-oriented..." (Greenberg et al., 2018, p. 12152).

This extensive $(N=671,606)$ analysis used an age cutoff from $16-89$ yearolds and assumed results likely reflect a multi-factorial interaction of biology (fetal T levels) and socialization (Greenberg et al., 2018).

Psychiatrist Norman Doidge (2008), and others (Finkel, 2012; Bao \& Swaab, 2011) argue the brain itself is neuroplastic; that is, one's experiences can affect one's neural pathways. As a result,

...it is impossible to discern the degree to which group-level differences between human males and females are attributable to inborn sex factors versus social, environmental gender learning...

(Eliot et al., 2021, p. 3).

According to Doidge (2008), the only adequate explication of neuroplasticity is that every sustained neural activity changes the brain and mind - including physical, sensory, learning, thinking, imagining, and cultural activities.

Such a deduction is arguably both socioenvironmental and a return of Lamarckism, the idea that experience can influence one's genes and those of one's offspring (Finkel, 2012). Likewise, neural plasticity reveals increased activation of specific cortical regions after several days of empathy training (Singer \& Klimecki, 2014), though empathy training in males appears to be less effective (Stuijfzand et al., 2016). Nonetheless, considering differences as taxonomic and produced regardless of how a child is raised, nurture may merely influence the average degree of innately focused difference (Sisk, 2016).

The actions of others activate a human mirror system of cortical networks in the self. This automatic response may have adaptive value for individual survival. In essence, "empathy plays a central role in moral reasoning, motivates prosocial behaviors, and inhibits aggression toward others" (Decety \& Lamm, 2006, p. 1146). Data suggests these mirror systems are more highly recruited in females (Schulte-Ruther et al., 2008). Counterintuitively, it would appear men and women activate similar neural circuitry in emotional processing, and differences in the level of empathy between males and females seem small to moderate. The reductionist conclusion is that betweengroup differences are hidden within-groups (Eliot et al., 2021).

In line with motherly behavioral tendencies and intuition across the lifespan, newborn girls just a few hours old show more interest in human faces and more sensitivity to tactile, oral, and visual stimuli (Jones \& Lopez, 2014). Despite the caveat that the first few hours after birth could play some role (Rippon, 2019; Jones \& Lopez, 2014), sex differences in behavior have been observed in the first few post-natal days (Connellan et al., 2000).

The amygdala is a critical element in emotion perception and processing (Pallayova et al., 2019). This region has also been shown to be sexually dimorphic (Pallayova et al., 2019; Lotze et al., 2019; Reber \& Tranel, 2017), and its nuclei have connections to other limbic areas (Crestani et al., 2013; Bonelli \& Cummings, 2007). The amygdala mediates empathy (Kolla et al., 2021) and empathy inhibits aggression (Decety \& Lamm 2006). In studying neural correlations of empathy in boys with conduct disorder, von Polier et al. (2020) emphasized the amygdala's significant role in empathy-related 
emotional processing, notably, a reduction in amygdala responses in association with low levels of empathy.

Vigil's (2009) introduction of a contingency model or a "framework for understanding phenotypic variation in expressed emotion" presents sex-typical emotive behaviors coevolved "to regulate interpersonal dynamics to enhance social fitness" (Vigil, 2009, pp. 375,376). Generally, contingent behavior is part of social interaction. For example, the first emotive gestures, such as smiling, are produced by human neonates after face-to-face social interaction (Vigil, 2009). Very young infants show contingency between a stimulus and their response and neutral stimuli, such as blowing on baby's belly each time they jiggle their legs. Contingent stimuli quickly become a trigger for smiling and cooing. The contingency is most striking with face-to-face contact with the mother, where a baby's smiling response may occur as early as the third day (Watson, 1972). Additionally, in response to a baby's cry during the first few postpartum weeks, there is increased activity in both parents' limbic brain regions (Swain, 2007).

Levels of empathy then are dependent on many factors, including genetics, age, education, income, and relationship status. Self-reported empathy in men and women always appears more significant in women; however, the gender gap closes in older age. Nevertheless, empathy levels do not begin to drop significantly until age fifty when sex differences become successfully smaller (Schieman \& Van Gundy, 2000), hardly insignificant considering the average age of menopause across 10 western and Asian countries is around 50 (Mishra et al., 2019). Concerning mothering, females are better at detecting expressions (LoBue \& DeLoache, 2009), and a mother must resonate with the state of her infant's helplessness, meaning she must possess empathy and maternal synchrony (see Atzil et al., 2011). So, of course, a mother's empathy levels would be independent of her age from adolescence or her fifth decade.

Females are hardwired for empathy and emotion recognition (Zaidi, 2010). Moreover, females exhibit higher rates in simple forms of empathy; contagious crying, neonatal imitation, social referencing. The different empathy patterns remain stable or grow larger with age (Christov-Moore et al., 2014) until after menopause as we have seen. Across development, females appear to be especially sensitive to perceived interpersonal threats. For example, females show a greater tendency toward more substantial startle potential (McClure et al., 2004). The key phrase here is 'across development.' Interestingly, women who engage in crime do so more to protect relationships (Broidy et al., 2003).

Consistent with results in several previous studies on empathy (females $>$ males) and autism, a large study of online participants $N=1098$ (304 males), average age 21.94 years, females scored higher on all scales measuring empathy. Additionally, for autistic and systemizing tendencies, males $>$ females (Sindermann et al., 2019).

An fMRI investigating gender-related differences in brain regions supporting empathy recorded regions involved in the human mirror neuron system (particularly the inferior frontal gyrus and Brodmann's Area) are recruited during emotional perspective-taking in both males and females. However, activation is more substantial in females in the right inferior frontal gyrus and 
right superior temporal sulcus (Schulte-Ruther et al., 2008). Their finding follows previous reports about differences between the sexes in the lateralization of brain functions (see, for example, Cahill et al., 2004).

By directly comparing meta-analytical literature of fMRI and positron emission tomography (PET) neuroimaging for women and men's emotional and neural responses to the same positive and negative stimuli, regional activation differences were noted notably in the amygdala and hippocampal activation. As well, sex differences favoring women were observed for negative emotion, with less activation in men on the same negative stimuli. The converse was noted for both sexes for positive emotion (Stevens \& Hamann, 2012). These results parallel other findings from the behavioral and psychophysiological literature on substantial sex differences (Yang et al., 2018; Zell et al., 2015; Heberlein et al., 2008; Swain et al., 2007), including response to fear (Zell et al., 2015).

The mixed results so generally problematic in sex and gender difference research could be better interpreted by moving from a single brain to a multibrain frame of reference. The notion that inter-regional crosstalk may increase as individuals become empathically engaged (Raz et al., 2014) is promising. The study by Raz et al. (2014) claimed unique evidence for activity between multi-factorial circuits or inter-regional crosstalk as the neural bases of empathy and the interaction of these circuits with subcortical limbic structures during the intensification of empathic engagement, which is also contextdependent. In terms of reproduction, context-dependent does not equate with an insignificant difference. The Raz et al. (2014) study participants were all adult females and having lived a substantial number of years would typically be regarded as a confound, and would instead plausibly account for developmental differences due to socialization and opportunity to empathize.

Though empathy activates equal brain regions in males and females, there is the probability there are reliable male/female differences in specific populations under particular conditions (Eliot et al., 2021). This observation could, with little doubt, be related to childbirth and the rearing of infants. Overall, the evidence suggests there are stable differences in empathy levels across the lifespan relevant to reproductive behavior and care of offspring and we believe it is not valid to claim differences in empathy levels, whether innate, learned, or both, are irrelevant sex differences in behavior at any age.

\subsubsection{Empathy in Childhood}

Sex differences in human behavior are expressed in the first few post-natal days. Female neonates and young girls prefer looking at human faces, while male infants look more at mechanical mobiles (LoBue \& DeLoache, 2009; Connellan, Baron-Cohen, Wheelwright, Batki, \& Ahluwalia, 2000).

Day-old neonates demonstrate sexual dimorphism in both social and mechanical perception. Male infants show a more substantial interest in mechanical objects, while female infants show a more substantial interest in the face. The male preference could not merely be for a moving stimulus, as both stimuli moved.

(Connellan et al., 2000, p. 116).

"The evidence linking early testosterone exposure to sex-typed play is particularly robust" (Hines, 2020, p. 37). Toy preference, faces versus things, 
and play preferences in children are apparent as early as age six months (Kung et al., 2018; Berenbaum \& Beltz, 2016; Jones \& Lopez, 2014; Alexander, 2003 ) and all with scant social experience. According to one researcher, "...parents do not have to coerce or coax boys to play with toy weapons, and parents do not have to force or teach girls to play with dolls" (van der Dennen, 2005, p., 3). It is also possible "that boys like toys that can be moved in space" (Hines, 2011, p. 74).

Studies with monkeys bearing similar results highlight how toy preferences cannot be explained simply by social pressure (Bao \& Swaab, 2011).

In a small study $(N=70)$ of one-year-olds and matching fetal testosterone to infants, girls made more eye contact than boys suggesting an inverse relationship between fetal testosterone levels and eye contact (Lutchmaya et al., 2002). Eye contact has previously been associated with sociability (Baron-Cohen et al., 1999).

In the end it is irrelevant if empathy is totally innate, partially innate, or purely socially acquired. What matters is what drives the behavior and that the behavior appears strongly dimorphic. The same can be said of aggression.

\subsection{Aggression}

The primate family that includes humans, Hominidae, is characterized by larger males than females, robust bodies, well-developed forearms. High levels of male-on-male aggression further characterize them, and aggressive behavior has been essential in the human evolutionary past (Carrier et al., 2011). Given male-on-male and intergroup aggression in the past and present Anthropocenes in competition for resources, including females and reproduction (reproductive fitness in Darwinian terms), it is possible natural selection for aggressive behavior in males, was one factor influencing the evolution of a larger muscular-skeletal system (Carrier et al., 2015). But we can still ask was this natural selection driven by biology or the social environment?

Arguably the evolutionary development of higher levels of aggression in males could have resulted from a socioenvironmental influence in that early Hominidae females were occupied with child care (feeding) and needed to be protected and available for their offspring and so unavailable to compete (hunt, aggress). Equally though contrary, the fact that only women lactate could be argued as a biological reproductive influence for the evolution of higher levels of empathy in females.

Aggression is widely accepted as having two forms - direct or overt, and indirect, covert, or social. Direct aggression encompasses direct verbal or physical confrontation, whereas indirect aggression uses social means such as gossip, character attacks, rumor-mongering, rejection or exclusion, and manipulation of peer relationships (Card et al., 2008). In childhood, boys lean toward physical aggression while girls lean toward social aggression (Li et al., 2020; Ligthart et al., 2005).

Furthermore, a person's "Sex is among the strongest correlates of criminal offending" (Broidy et al., 2003, p. 503). The discrepancy in levels of direct contemporary aggression between men and women remains striking. 
Men are more likely to show physical aggression. They commit $89 \%$ of all murders and $99 \%$ of all sexual crimes, while women are more likely to engage in acts of indirect aggression: spreading vicious rumors, gossiping, or fabricating stories about that person.

(Bao \& Swaab, 2011, p. 220).

A dominance of testosterone around birth and at about nine weeks of gestation results in masculinization of the brain and genital tract (Zuloaga et al., 2009; Wizemann \& Pardue, 2001), and males of all ages, including prenatally, have substantially higher T levels than females (Lonstein et al., 2014).

Accordingly, there is strong evidence for sex differences in the sympathoadrenal nervous system's neural control (Hinojosa-Laborde et al., 1999). At rest, plasma noradrenaline (norepinephrine) levels are consistently higher in females and adrenaline (epinephrine) levels higher in males (Davidson et al., 1984), and men and women react differently to stress, both psychologically and biologically (Kret \& De Gelder, 2012).

Findings from neuroimaging record response patterns to stress in the HPA axis and sympathetic nervous system differ markedly between males and females. Female sex hormones lessen the sympatho-adrenal and HPA responsiveness. The amygdala region is broader in ciswomen with a higher estrogen density than androgen receptors (Halpern, 2013). Furthermore, as we saw, the amygdala mediates empathy (Kolla et al., 2021) and empathy inhibits aggression (Decety \& Lamm 2006). Yet, according to Gina Rippon (2019), nobody knows for certain whether having a bigger amygdala [or putamen] makes you more or less aggressive.

In support of the hypothesis that prenatal biology influences post-natal social behavior, fetal testosterone levels in typically developing children measured via amniocentesis and compared to their infant levels (age range 6-9 years) revealed a strong inverse correlation with empathy scores for males (Chapman et al., 2006). Empathy is higher on average in females than in males and appears to be reduced by fetal testosterone exposure (Hines, 2011). Unsurprisingly, psychopaths exist across all cultures and ethnic groups, and psychopathy occurs more frequently and typically more violently in men (Wynn et al., 2012). Interestingly, structural and functional magnetic resonance imaging (MRI) has revealed core psychopathic features are associated with frontotemporal regions and frontotemporal, limbic, paralimbic, and cerebellar structures (Johanson et al., 2020).

Human babies have an extended juvenile period. Care of such dependent offspring requires teamwork from parents that subsumes attachment, suckling, emotional nurturance, and parental sensitivity to danger (Christov-Moore et al., 2014). For primitive fathers, aggressive behavior was a social conduct essential in competition for food, territory, and mating (Gouveia et al., 2019). For contemporary fathers, the care of offspring may also involve physical aggression in the forms of territorial defense and acquisition of resources (Meyer-Bahlburg, 2019), i.e., the view of aggression outlined below. Human babies and their mothers require security and support in resources for many years before babies are considered mature, and a partnered father must resonate with the state of his family's needs. 
As a master regulator, $T$ plays a significant role in the arousal of brain centers involved in aggression and the muscular system's development that enables aggression's realization. The neural network components that regulate aggressive behavior include the amygdala, the hypothalamus, the putamen, and the orbitofrontal cortex (for review, see Gouveia et al., 2019; Unger et al., 2015). T acts through the interplay between subcortical structures in the amygdala and the hypothalamus (Unger et al., 2015; Batrinos, 2012). Gonadal steroid levels are increased in a sex-specific manner. During the fourth to the fifth month of pregnancy, a surge of fetal T occurs lasting a few weeks (Hines, 2020) to reach adult levels that inundate the male brain inducing anatomical and organizational changes (Batrinos, 2012).

Post-natally, $\mathrm{T}$ levels peak in boys at 1-3 months of age and decline at six months of age (Kuiri-Hänninen et al., 2014) until puberty. T levels in adult males, i.e., after physical development, average 10 - 20 times higher than adult females (AACB, 2020). Higher T levels for women are associated with lower maternal behavior (Smith et al., 2015). Girls with congenital adrenal hyperplasia $(\mathrm{CAH})$ show more aggression than non-affected siblings (CohenBendahan et al., 2005).

Further, male empathy levels appear to be reduced by the higher $\mathrm{T}$ exposure in-utero (Hines, 2017), and men with lower T levels demonstrate increased parental responsiveness (Lonstein et al., 2014).

In reply to criticism of her book Testosterone Rex (Fine, 2017) and her analysis of distorting effects of assumptions about sex differences, Cordelia Fine suggests hundreds of studies mistakenly claim differences in prenatal $\mathrm{T}$ hardwire gender identity (Fine et al., 2019). That suggestion is in stark contrast to observations that in the final periods of fetal development, the masculinization and defeminization processes of the hypothalamus are dependent on T secretion (Acevedo-Rodriguez et al., 2018). Similarly, males of all ages have substantially higher T levels than females (AACB, 2020), or that during early pregnancy, a surge of fetal $\mathrm{T}$ reaching adult levels occurs in the male fetal brain (Batrinos, 2012).

Aggressive and anti-social behavior is linked to prioritized genes highly expressed in the amygdala and putamen, as well as in the cerebellum and frontal cortex (López et al., 2020). Sex differences in copulatory and postcopulatory behavior might be considered adaptations that serve particular evolutionarily and social needs, so long as the adaptions do not favor the evolution of groups over individual evolution and vice versa (Parker, 2021).

It seems some brain and psychiatric disorders are programmed prenatally as dimorphic in the brain (Ritchie et al., 2018; Bao \& Swaab, 2011; Vigil, 2009, Negri-Cesi et al., 2004), though likely along a spectrum of expression and responsiveness as every other disorder. Aggression is a prominent feature in many children with neurodevelopmental disorders. Aggression is more highly associated with boys in adolescence. Perhaps further insight into T's sexspecific effects can be better inferred from sex-related disorders in young subjects (Negri-Cesi et al., 2004) and twin studies.

T's early effects are highlighted in the study of same-sex (SS) and oppositesex (OS) 16-year-old twins. OS girls (girls from boy/girl twin sets) showed a 
more masculine behavior pattern than SS girls (girls from girl/girl twin sets) with no differences in T levels or pubertal status. The twin study supports T's prenatal levels as higher for OS girls and adds backing for sex differences in aggression overall, similar to CAH girls who show more aggression than nonaffected siblings (Cohen-Bendahan et al., 2005). In contrast, studies reveal CAH girls "do not differ from other girls in spatial ability, verbal ability, language lateralization, handedness, or aggression, but may prefer "boy toys" as children and later have decreased sexual interest in men" (EricksonSchroth, 2013, p. 159).

The coupling between cortisol, dehydroepiandrosterone (DHEA), and testosterone are potential mechanisms for destructive behavior in $(N=50)$ extremely antisocial adolescent males (mean age 16.08 years). An endproduct of the HPG axis is T secreted by the testes (Johnson et al., 2014). In the HPA and HPG axes, these hormones have common effects in moment-bymoment response to stress, for example, momentary fluctuations in cortisol, testosterone, and DHEA. The abnormal functioning of these hormones may be related to destructive behavior. The authors suggest "HPG-axis functioning could be so powerful that it recruits the HPA...to operate in an androgenergic manner leaving afflicted individuals with the biological potential for sociopsychopathic behavior (Johnson et al., 2014).

In humans, aggressive behavior is social conduct typical of ancient Anthropocenes, where it was essential in the competition for food, territory, and mating (Gouveia et al., 2019). It has been argued that lethal conflict, war, arose in the evolutionary context of reproductive striving. According to this view, reproductive competition in warfare can be seen as a significant evolutionary selective force waged in the name of women, bridewealth, revenge, food resources, and territory (Low, 2015). While empathy training exists (Singer \& Klimecki, 2014), aggression, and not empathy, can be formally studied to Ph.D. level in the form of 'War Studies' (Kings College, London).

Males score higher than females on measures of aggression (Hyde et al., 2018) and spatial processing [resource attainment] (Reber \& Tranel, 2017; Hyde, 2005). Moreover, the magnitude of difference is the largest favoring males in situations with the most danger (Hyde, 2005). In mice, the ventromedial hypothalamus is more responsive to males' presence than to females. This response may play a role in male aggression (Wong et al., 2016).

A species' future rests with "the ability of its members to coordinate behavioral responses with physiological processes in response to sexually relevant cues" (Simerly, 2002, p. 508). Within the framework of evolutionary theory, who reproduces best, survives (Low, 2015).

\subsubsection{Aggression in Children}

Boys tend to enact more direct aggression than girls while girls enact more indirect aggression (Card et al., 2008). The expression of indirect aggression, on the other hand, is similar between boys and girls with trivial differences in magnitude and with the two types more intercorrelated in boys (Card et al., 2008). 
As children age, they increase their social skill levels, and more sophisticated approaches to aggression become possible. Nonetheless, social aggression increases drastically at about age 11, especially in girls, and is arguably a learned skill. As girls mature, they become more outstanding in social intelligence and, due to their lower muscular strength, rely more on indirect aggression (Björkqvist, 1994). This outcome is in accordance with girls and women's response to a threat with 'tend and befriend' rather than 'fight or flight' (Verma et al., 2011).

In a study of 14-year-old twins focusing on relative life-naivety, aggression is a prominent feature in many children with neurodevelopmental disorders. Across an entire sample population, aggression was positively associated in male children and increased putamen volumes (Yang et al., 2017).

Moreover, aggression is a highly hereditary and stable trait across all ethnicities, cultures, and age groups (Ligthart et al., 2005). Children with early-onset conduct disorder show severe levels of aggression (von Polier et al., 2020). Decreased functional activity in the putamen was significantly associated with physical aggression in a study of $9-12$ year-olds ( $\mathrm{Li}$ et al., 2020).

It can of course be argued with some weight that differences in empathy and aggression are the result of socioenvironmental conditions from a very early age. We reiterate this paper is not so much debating the origins of sex-linked differences, merely their existence and what this means to notions of gender identity.

\subsection{Aggression by another name}

Testosterone levels in males of the modern Anthropocene remain high (AACB , 2020). All forms of aggression - direct, indirect, reactive, proactive - can be adaptive (competitive) or maladaptive (Orobio de Castro et al., 2005). Following Hare (2017) and Huber and Kravitz (2010), contemporary aggression can be regarded as a distant cousin to ancient aggression and viewed more helpfully, less aberrant, and more positively as heroics or a competitive spirit related to mate selection, supply, and defense of resources, self-defense, and defense of significant others.

A philosophical view of aggression presents masculinity as manifesting itself in cruelty and violence (Weigel et al., 2020). Within the 21 st-century Anthropocene, such aberrant masculinity is non-essential (Meyer-Bahlburg, 2019). Nonetheless, aggression has not yet evolved out of our species, perhaps simply because aggression remains relevant nowadays when aligned more positively with 'heroics, a competitive spirit related to mate selection, supply and defense of resources' etcetera, as Huber and Kravitz (2010) proposed. While the defining characteristic of the human domestication syndrome is dampened reactive aggression, i.e., a decrease in physical aggression and fear (Hare, 2017), unfortunately, as with all human behaviors, some individuals and societies misuse their natural tendencies at an individual and group level and aggressions usefulness has not yet had evolutionary time frames to de-evolve.

A contemporary notion of aggression understands it as a competitive spirit alongside a willingness to mount violent defenses against outsiders signifying 
a kind of natural selection for friendliness and characteristics that enhance mating ability, survival, and reproductive success (Sunstein, 2020).

\subsection{In short}

We have presented differential networks as reflected in the specific behaviors relevant to reproduction stemming from the RA. After heterosexuality, the two most notable differences in cognitive behaviors discussed here occur concerning offspring's care as empathy and aggression. We also present the emergence of a subconscious awareness of this reproductive axis as gender.

In a tiny number of people, 390 to 460 per 100,000 [0.4\%] (Leinung \& Joseph, 2020), or $0.5-1.4 \%$ of natal males and $0.2-0.3 \%$ of natal females (Theisen et al., 2019), the alignment of body sex and gender identity is unconventional or incongruent. It would be remiss or deemed transphobic to focus on gender identity without exploring some research into sex/gender diverse communities.

\section{EXEGESIS FROM SEX / GENDER INCONGRUENCE}

As a reproductive axis must exist in trans and non-heterosexual individuals alike, we should not assume any gender dysphoria in the trans community is caused by socioenvironmental factors alone. If there is no internal biological locus for gender identity, what is it trans individuals of all ages, but especially the very young, feel is inconsistent with their biological sex? There is an emboldened proposal that there is "no evidence that one's postnatal social environment plays a crucial role in gender identity" (Bao \& Swaab, 2011, p. 214).

\subsection{The importance of treatment naivety in research}

Trans studies have faced many confounding issues (Fine, 2020; Byne et al., 2018; Hyde, 2005). Neuroimaging research shows the role of hormone therapy in the cognitive tasks of trans individuals appears strong (Kristensen et al., 2021; Nguyen et al., 2018; Wierckx et al., 2014) and the effects of hormone therapy or years already lived cannot be ruled out in behavioral studies. The most influential confounds in our opinion are the scarcity of early-onset and treatment naïve studies. Any trans research that does not incorporate these exclusion and inclusion criteria makes it very difficult to establish cause and effect. It was imperative for our review into the trans population that only studies of hormone naïve individuals can be considered valid and relevant.

A sex/gender mosaic appears to bypass the biology of trans children who identify as gendered opposite to their natal sex, some as early as age two (Zucker et al., 1997), or age three (Olson \& Gülgöz, 2018; Hewitt et al., 2012) and irrespective of what their body structures are scaled to fit in the future. It also disregards children who persist post-puberty, whose reproductive behavior is not always conventional, and late-onset dysphoric individuals who identify with a gender opposite to their birth sex. Our hypothesis speaks directly to early-onset trans individuals. 


\subsection{Timing is everything}

Fetal somatic and neural development are temporarily displaced, and "The theory of the origin of transsexuality is based on the fact that the differentiation of sexual organs appears well before the sexual differentiation of the brain" (Bao \& Swaab, 2011, p. 217). This temporal and physical displacement of body and brain developmental means it is possible for the "sex of the genitalia" and "brain gender identity and sexual orientation" to become discordant (Tasopoulos, 2018) or incongruent (Roselli, 2018).

\subsection{The trans community}

With the recent claim that the human brain is not sexually dimorphic, Eliot et al. (2021) suggest "popular discourse about the 'male brain' and 'female brain' as clearly distinct" has been disproved (Eliot et al., 2021, p. 80). This has the potential to delegitimize the validity of all trans communities. The reproductive axis is common to cis and trans identities, making the trans community another candidate in examining neural subsystems as the source of gender identity.

Along with their temperament (Kelsey et al., 2021), newborns and very young humans demonstrate differentially gendered behavior (Jones \& Lopez, 2014). Children are "the most intransigent of gender police!" (Rippon, 2019, p. 341). Furthermore, researchers should assume that many cisgender individuals including children feel at some stage similarity to both the categories 'male' and 'female' (Hyde et al., 2018). A very few individuals however feel an overarching sense of unease over their gender. We now refer to distress resulting from this unease as gender dysphoria (GD) (Sánchez \& Vilain, 2013). Late-onset gender dysphoric individuals are those whose earliest memories are filled with similar unease yet not acted upon until later adulthood mechanisms come into play.

"If an individual says there is something amiss with their biology-gender link, then perhaps it would be productive to challenge the link as well as the theory of any prelabeled box" (Rippon, 2019, p. 343) of gender identity. "It may just be that there is a problem with the question of what makes a boy or a girl" (Rippon, 2019, p. 343).

We prefer to offer an alternative position that may be of positive use to the trans community. The history of debates on the existence or otherwise of sexlinked origins has not served the well-being of many marginalized groups well in terms of global respect and equality (Roth, 2015). Our biologically reductive narrative may be appropriate given certain behaviors are necessary for the reproduction of the species and we suggest focusing on what is it very young and persisting adult trans individuals feel is inconsistent with their bodily sex assigned at birth.

Between age two to five, most children have an awareness of their gender (Ruble et al., 2007; Ahmed et al., 2004). Moments after birth or before, a child's interaction with the world can begin to signpost gender stereotypes and their different directions (Rippom, 2019).

Nevertheless, "Where does this atypical gender desire come from? Why have trans [individuals] not succumbed to the same influences of social and cultural attribution that have others?" (Diamond, 2000, p 3). "Why does the mind take 
precedence?" (Diamond, 2000, p. 4) over the body. Milton Diamond is of the opinion early engrams (see 10.1 later) are biologically fixed by pre-natal genes and hormones and are more potent than socialization pressures (Diamond, 2000).

So we chose to ask is there biology behind what motivates these young children to question their gender when debatably they have not had sufficient socioenvironmental exposure to absorb and learn the gamut of nuances or the politics of sex and gender. This can be regarded as especially significant when you consider a very young brain cannot accurately predict much of its future based on past knowledge. Thus it seems illogical to expect a very young child to choose an opposing gender identity based on minimal input gleaned from society. Additionally, the gravity of a wish to live as female becomes more obvious when we consider societies favor males (Amosu, 2019; Bashir, 2017; McDonald, 2021) and particularly during their adult careers (Rippon, 2019). Moreover, why and what is it that drives a mature age individual to act on their dysphoria and "seek to reconstruct their sex to coincide with their psychological gender" (Diamond, 2000, p 2) when setting about "learning or perfecting how to be the man or woman of mind's desire" (Diamond, 2000, p. 2), will, for many, severely negatively impact their life, and not doing so results in $63 \%$ reporting previous self-harm, and $43 \%$ attempt suicide (Zwickl et al., 2021).

Based solely on the socioenvironmental origins of gender identity and the lower standing of females across much of the world, it would be more logical to expect the numbers of FtM individuals to far exceed those of the MfF when in fact it has up to recently been the opposite. In contrast however, the numbers of people identifying as trans has been rising, the age of identification dropping, and reportedly the numbers of FtM individuals has reached that of the MtFs (Leinung \& Joseph, 2020), though the numbers of desisters is also growing (Steensma et al., 2011).

Intense pre-pubescent dysphoria persisting into adulthood is an essential DSM $\mathrm{V}$ requirement for the diagnosis of GD. While not all trans individuals share early onset symptoms (Saketopoulou, 2014), age six months to five years seems insufficient time to learn the political and socio-cultural structures of gender without gender having some prior form of influence, namely biological and in utero. If gender is an entirely social construct, all hair, and makeup, as has been implied (Rippon, 2017; Butler, 1990), pre-puberty (ages 3-12) is arguably a time when most gender opposite children, with or without any dysphoria, are unlikely to have sufficient time to comprehend their dissonance nor any competing script to how they feel and especially considering gender non-conformity has been shown as early as age two (Vance et al., 2014).

The putamen, thalamus, hippocampus, hypothalamus, and amygdala regions deemed dimorphic in the cisgender community have been shown to be dimorphic and unconventional in the trans community. In treatment, naïve trans individuals, TBV matches that of their birth-assigned sex (Manzouri, Kosidou, \& Savic, 2017; Hoekzema et al., 2015). In early-onset (treatmentnaive) FtM and MtF individuals, gross brain morphology in various areas such as cortical thickness, white matter microstructures, ER $\alpha$, and ER $\beta$, suggests 
their atypical or multifaceted brain sex development (Fernandez et al., 2018; Rametti et al., 2011).

Amygdala volume in MtF subjects is consistent with their sex at birth, not their gender identity (Mueller et al., 2017), and female-type connections within the amygdala have been reported (Manzouri, et al., 2017). There are different cerebral integration profiles of female-to-male (FtM) and male-tofemale (MtF) individuals (see Kreukels \& Guillamon, 2016). Hormone naive FtM trans individuals follow natal female hippocampal differences (Manzouri et al., 2017), and the amygdala and hippocampus develop with size and neuron numbers closer to the desired rather than natal sex (Smith et al., 2015).

Additionally, the cortex of hormone naive homosexual MtFs and FtMs is feminine and has an $\mathrm{F}>\mathrm{M}$ morphological pattern of difference (Guillamon et al., 2016). How can such pathways exist before very young trans children absorb cultural and social influences?

The MtF brain is reportedly not uniformly femininized but shows a mixture of masculine, feminine, and demasculinized anatomy (Rametti 2010).

Furthermore, the FtM brain is not uniformly masculinized but shows a mixture of feminine, masculinized, and defeminized morphology. Both morphologies are different from heterosexuals supporting the intersex brain hypothesis of the trans community (Guillamon et al., 2016).

Trans studies alone do not locate gender; nonetheless, our suggested biological component of gender highlights the multifactorial basis for gender identity and how various regions within the reproductive axis could be a part of the gender network. For example, estrogen's actions on the developing hippocampus, cortex, cerebellum, hypothalamus, and amygdala are generally permanent and range from the establishment of dimorphic sex differences to generalized effects (Fernandez et al., 2020). As we saw, T's actions "in the final periods of fetal development are fundamental for the processes of masculinization and defeminization of the hypothalamus" (Acevedo-Rodriguez et al., 2018, p. 11).

As was noted previously, the strength of sexual dimorphism in the cisgender is likely homogenous across all of the RA. Simultaneously, the pattern for causes of incongruence in the trans community suggests sexual dimorphisms may be heterogeneous, i.e., any or many, leading to many phenotypes across a spectrum of expression. Additionally, the bio-psycho-social approach to the study of trans individuals is again highlighted because the reasons any one individual identifies as trans are likely numerous (Erickson-Schroth, 2013).

While causes for gender incongruence may depend on a milieu of origins, we suggest we are left to acknowledge current theories surrounding biological differences between cis and trans individuals involve regions of the RA, specifically the limbic system. This provide further support for the probability that the RA's physiological regions form a neural location for gender, physically and temporally separate to body sex and at least in part.

While many similar structures have been implicated in trans and nonheterosexual subjects, most non-heterosexuals are not trans, and some trans individuals are heterosexual. Non-cisgender individuals are less likely to reproduce as much as the cisgender population (Swaab \& Garcia, 2009) and 
therefore tend more toward reproductive isolation despite their permanent place in evolution (Rice et al., 2012).

\subsection{Persisters and Desisters}

While debates about the validity of labeling children as persisters and desisters have been prominent (Temple-Newhook et al., 2018; Zucker, 2018), permanent morphological changes in the CNS of persisters may occur due to exposure to steroid hormones at approximately the time of birth. Additionally, overt genital anatomy "will radically shape the child's social environment" (Zuloaga et al., 2009, p. 352), or earlier if the sex of a child is known antenatally.

Lisa Diamond believes children recognize gender attributes as early as $9-12$ months of age, (Diamond, 2000). Most children express their sense of gender and label others as conventional by age two or three (Ahmed et al., 2004; Leinbach \& Fagot, 1986). After children know they are girls or boys and engage in activities they identify as appropriate for their sex (Hines, 2020). During adolesence "Pubertal hormones likely contribute to the dramatic changes in behavior and brain structure." Brain maturity during this period as measured in amygdala and hippocampal volumes, contributes to emotional regulation differences in girls and boys (Frere et al., 2020).

In agreement with these 'drastic changes', the "emergence of sex differences in mood and anxiety disorders during adolescence may relate to sex differences in brain development or sex differences in pubertal hormones" (Marsh et al., 2008, p. 7). On the other hand, children experiencing GD preand post-puberty (persisters) do not appear to be affected by puberty's usual sex hormone activations (Guillamon et al., 2016).

Many early-onset trans individuals, anywhere in the order of $70-98 \%$ (Steensma et al., 2011), may desist and return to their cisgender life both due to the resolution of difficulties other than sexual dimorphism and natural sex hormone changes in puberty (Gliske, 2019). Others propose, "It would be surprising if the large orientation differences in childhood gender nonconformity disappeared without a trace by adulthood" (Bailey et al., 2016, p. 58). For example, childhood occupational and recreational interests appear to linger into adulthood (Bailey et al., 2016).

In the pubescent children who 'desist,' the activational effects of adolescent sex hormones and environment might play a significant role in reversal of their mindset (Guillamon et al., 2016). Crucially, the percentage of 'desisters' does not number $100 \%$.

A possible explanation for all of these findings could be differential gene expression produced by some epigenetic process that would affect androgen receptors and/or their equilibrium with estrogen receptors in certain regions of the cortex of transsexuals. This observation could help provide a hypothesis that supplies a single explanation for the cortical phenotype in MtFs, FtMs, and controls (Guillamon et al., 2016), that is, a trans gender identity may be the result of gene and epigenetic interference as has recently been implied (Fernandez et al., 2021).

In late-onset trans individuals, synaptic plasticity (Tozzi et al., 2019; Gräff et al., 2011) and "Intermittent or repeated stress exposure may place a greater 
load on HPA-HPG equilibrium...the actions of gonadal hormones to mediate adaptive neuroendocrine and behavioral responses, may be completely impaired in the face of chronic stress exposure..." (Toufexis et al., 2018 p 12) and may also account for how changes to sex hormones in aging contribute to late-onset dysphoria.

\section{DISCUSSION}

It is very difficult to impossible to separate the influences of biology and culture from one another (Joel et al., 2020; Fine et al., 2019) or consistent sex differences in brain structure to more fickle sex differences in brain function" (de Vries \& Södersten, 2009. When differences are context-dependent across domains, it becomes even more complicated unravelling sex and gender discussions (Del Giudice et al., 2012), and more so when it may not be acted upon until adolescent hormones kick in (Jones \& Lopez, 2014) or even in later life.

Methodological questions abound. Should researchers adjust for raw neuroanatomical volumes as many have done, considering, as Rippon (2019) highlights, there is no agreed standard as yet? Also, statistical significance does not necessarily equal scientific relevance, and $p$ values in statistics do not measure the living importance of a result. A 'small' effect size does not equal a trivial effect (Sanchis-Segura et al., 2019).

Some authors have not made what we consider a meaningful distinction between general cognitive behaviors and those relative to reproduction, choosing instead to consider behaviors related to 'reproduction' as physical and nothing more, seemingly bypassing limbic system function relative to reproduction. "From flies to mice and rats, sex behavior is controlled to match the reproductive capacity of each individual and the availability of resources" (Lenschow \& Lima, 2020, p. 164).

In this review, we have hopefully separated general behavior from cognitive behavior relevant to reproduction and maintained the RA, specifically the limbic system, as the central network of gender identity. This separation allows us to see how pubescent children who consistently, persistently, and insistently (Olson \& Gülgöz, 2018) maintain a gender opposite to that assigned at birth. This separation and the subsequent differentials arguably highlights a shortfall in viewing gender solely as a social category of sex/gender which appears to ignore both the very young pre-pubescent trans child who persists post-puberty as well as individuals who experience, reexperience, or relive a gender opposite to their bodily sex in later life.

Accepting sexuality as the global term concerning reproduction presented earlier (see Chodorow, 1999) and the differences in courtship, aggression, empathy, and care of offspring as essential to reproduction, the significance of the RA, and especially the limbic system, to gender identity, becomes clearer. While there will be some overlap in behaviors related to reproduction, and gender is not categorical, they are sufficiently polarized that average differences remain significant and relevant (McCarthy et al., 2017).

Borrowing from McCarthy et al. (2017), we can say a handful of sex differences in the CNS can be linked to differences in sexual (physical) behavior. Of most other (cognitive) sex differences, we can ask would 
dimorphic differences give males and females any advantage in terms of function. Humanity endures through a cycle of reproduction and survival, and the claim that human behavior is, therefore, dependent on associated physical and cognitive behaviors is a worthy one. That claim may also answer the hypothetical question of why we would have a gender at all.

If evolution has selected sex-specific organization relevant to reproductive fitness, then neural circuitry will also be a function of sex (Sisk, 2016). Sexspecific organization would include the socioenvironmental input. However, when it comes to emotions, even Darwin was puzzled. Emotional differences have still to be fully understood from an evolutionary perspective; nonetheless, according to the theory of phenotypic variation for expressed emotion, sex-typical emotive behaviors co-evolved to "regulate interpersonal dynamics that enhance social fitness" (Vigil, 2009, p. 376).

The adaptive significance of affective responses (e.g., emotions, dispositions, moods) lies in their expression and affective behaviors function to systematically motivate other people to respond to the signaler in ways that enhance the signaler's fitness"

(Vigil, 2009, p. 376).

The differential in reproductive burden indeed necessitates differences in physiology, psychology, environment, and effective responses that are characterized as gender differences.

The self-domestication hypothesis claims social skills evolved when natural selection favored increased self-control and group pro-sociality over aggression in late human evolution (Green \& Spikins, 2020; Hare, 2017). Accordingly, we can add that effective responses such as empathy and contemporary aggression as presented herein, are adaptive in that they aid the survival of offspring. Thus, the essence or engram of gender is our subconscious awareness of the reproductive part of our Id. According to Freud (1966), one part of individual self-concept is biologically driven and part is socially constructed (Author 1 , under review).

\section{Electromagnetic fields \& gender}

'Engrams' and 'Essence' are conceptually vague descriptors in neuroscience; however, when we adapt McFadden (2020), it is not so much how DNA or all the information from the 100 billion electromagnetic (EM) field transmitters and 100 billion EM receivers of cerebral origin come together to create the conscious perception of thoughts, gender, or anything else, instead, information encoded by the neurons is unified within a single brain electromagnetic (EM) field. "Every time a neuron fires, along with the matterbased signal that travels down its wire-like nerve fiber, it also projects a tiny electromagnetic pulse into the surrounding space..." (see McFadden 2021). This EM theory proposes "consciousness is physically integrated, and causally active, information encoded in the brain's global electromagnetic (EM) field" (McFadden, 2020, p. 1). EM pulses generated by neuronal firing flow into each other to generate a pool of energy called an electromagnetic field. Our (EM field-based) conscious mind encodes and unifies the information from billions of distributed neurons (McFadden, 2020). 


\section{CONCLUSION}

Our observation is that a part of the origins of gender incongruence in the trans community are similarly the source of congruent cognitive differences in the cisgender population, namely those related to cognitions linked to reproductive behaviors, highlights the similar biological origins of a network for gender identity. These reproductive behaviors are relevant to demands, specializations, responsiveness, cognitions, and especially empathy, aggression as related to the care of offspring.

All factors considered, we know that sex-related brain structures in the RA are at least partly distinguished pre- and post-natally, therefore EM biology drives this part of one's self-concept (recognized in Freudian psychoanalysis as the "Id"), while the other is socially constructed (recognized in Freudian terms as the 'Superego'). Similarly, in Jungian psychoanalysis, the "archetype" is where latent instinctual energies await development and expression.

A phenotype for gender variance is not likely restricted to a single network but rather to the interaction of multiple networks including endogenous and exogenous sources (Uribe et al., 2020), yet as research stands, there is currently no biological marker for gender. Up till now a framework of evidence for sex vs. gender in the reproductive axis of the cisgender and trans communities has not been presented previously.

As mentioned, not all who identify as trans suffer clinically significant distress prompting a diagnosis of GD. Some seek only limited therapy such as gender affirming hormones, other seek merely a social transition without medical intervention, and others wish only to be flexible in gender expression, identifying for example, as non-binary or queer (Byne et al., 2018). The search for a biological marker of gender could lie hand in hand with locating its anatomical network.

Montanez (2017) presented a striking visual representation of the convoluted pathways within the spectra of disorders of sex development (DSD), however, gender per se is not represented. Borrowing from Meyer-Bahlburg (2019) it may be recognized XX / XY genetic binaries canalize differentiated taxons. And the existence of intersex bodies, although rare, testifies to the overlapping of canalized bodily sex (García-Acero et al., 2020; Swaab \& Bao, 2016; Ainsworth, 2015). O'Hanlan et al. (2018) present an example of over 450 quadrillion possibilities of dimorphism, which we suggest is way of representing taxons numerically.

Combined with our unique human consciousness and self-awareness, essential cognitive and emotional differences described herein credibly make for our perpetual sense of gender, from which men and women adopt a gender role identity to express gender via individual gendered displays in their social world (West \& Zimmerman, 2009).

In conclusion, we propose that gender identity is the innate sense of ourselves as the EM field arising out of the interlinked networks of the reproductive axis. This network could be represented by the pseudo-equation: gender identity $=$ EMcortex + EMprefrontal cortex + EMpituitary + EMlimbic system (hippocampus, amygdala, hypothalamus). This "equation" does not represent how the various elements are necessarily additive and are not necessarily 
equally weighted. It does however represent the multifaceted components involved in gender identity as well as in gender incongruence. Furthermore, considering neural pathways, it would be difficult to argue differences in aggression and empathy do not filter into other neural networks adding to gender's canalization. Gender identity is therefore presented here as at least partially innate and aligned with our future reproductive roles as mothers and fathers.

\subsection{Postscript -The end of Gender?}

McCarthy and Arnold (2011) proposed X and Y genes are the factors at the root of all differences in the human phenotype, yet, some predict 'gender' as we know it may cease to exist in the distant future. Indeed the concept of "gender isn't what it used to be" (see Thurer, 2005). The premise of nonexistent gender can be regarded as ideological and based on social construction theory, with gender regarded as forming solely under the influence of parenting and society. However, the social construction of gender does not explain innate differences in reproductive cognitions between males and females presented herein.

\section{Declarations}

This research did not receive any specific grant from funding agencies in the public, commercial, or not-for-profit sectors.

Conflict of interest: The authors declare they have no conflicts of interest.

Human and Animal Rights: This article does not contain any studies with human participants or animals performed by the author.

\section{Disclosure statement}

No financial interest or benefit has arisen from the direct applications of this research.

\section{CRediT author statements.}

Author 1: Conceptualization; Project administration; Resources; Software; Writing - original draft \& editing; Writing - review \& editing.

Author 2: Project administration; Writing - review \& editing.

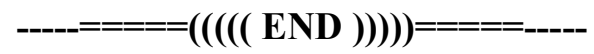




\section{References}

AACB (2020). Australian Association for Clinical Biochemistry and Laboratory Medicine. Retrieved from https://www.labtestsonline.org.au. Visited August 16, 2020.

Acevedo-Rodriguez, A., Kauffman, A., Cherrington, B., Borges, C., Roepke, T., \& Laconi, M. (2018). Emerging insights into hypothalamic-pituitary-gonadal axis regulation and interaction with stress signalling. Journal of neuroendocrinology, 30(10), e12590.

Ahmed, S., Morrison, S., \& Hughes, I. (2004). Intersex and gender assignment; the third way? Archives of Disease in Childhood, 89, 847-850.

Ainsworth, C. (2015). Sex redefined. Nature, 518(7539), 288.

Alexander, G. (2003). An evolutionary perspective of sex-typed toy preferences: Pink, blue, and the brain. Archives of sexual behavior, 32(1), 714.

American Psychological Association. (2015). Guidelines for psychological practice with transgender and gender nonconforming people. American Psychologist, 70(9), 832-864.

Amosu, O. (2019). Sexual Harassment in Illinois: Public Opinion and Legislative Action.

Atzil, S., Hendler, T., \& Feldman, R. (2011). Specifying the neurobiological basis of human attachment: brain, hormones, and behavior in synchronous and intrusive mothers. Neuropsychopharmacology, 36(13), 2603-2615

Author 1. (in review) Psychoanalysis and Neo-androgyny. International Journal of Psychoanalysis.

Auyeung, B., Wheelwright, S., Allison, C., Atkinson, M., Samarawickrema, N., \& Baron-Cohen, S. (2009). The children's empathy quotient and systemizing quotient: Sex differences in typical development and in autism spectrum conditions. Journal of autism and developmental disorders, 39(11), 1509-1521.

Bailey, J., Vasey, P., Diamond, L., Breedlove, S., Vilain, E., \& Epprecht, M. (2016). Sexual orientation, controversy, and science. Psychological Science in the Public Interest, 17(2), 45-101.

Bao, A., \& Swaab, D. (2011). Sexual differentiation of the human brain: Relation to gender identity, sexual orientation and neuropsychiatric disorders. Frontiers in Neuroendocrinology, 32, 214-226.

Baron-Cohen, S., O’Riordan, M., Jones, R., Stone, V., \& Plaisted, K. (1999). A new test of social sensitivity: Detection of faux pas in normal children and 
children with Asperger syndrome. Journal of Autism and Developmental Disorders, 29(5), 407-418.

Bartky, S. (1999). Femininity and domination. In C. C. Gould (Ed.), Key concepts in theory: Gender. New York: Humanity Books.

Bashir, S. (2017, April). Changing Gender Roles and Spousal Agreement on Fertility Intentions: A Case of Pakistan. In PAA 2017 Annual Meeting.

Batrinos, M. (2012). Testosterone and aggressive behavior in man. International journal of endocrinology and metabolism, 10(3), 563.

Batson, C., Duncan, B., Ackerman, P., Buckley, T., \& Birch, K. (1981). Is empathic emotion a source of altruistic motivation?. Journal of personality and Social Psychology, 40(2), 290.

Berenbaum, S., \& Beltz, A. (2016). How early hormones shape gender development. Current opinion in behavioral sciences, 7, 53-60.

Björkqvist, K. (1994). Sex differences in physical, verbal, and indirect aggression: A review of recent research. Sex roles, 30(3), 177-188.

Blair, J., McGee, H., Bhatta, S., Palm, R., \& Casadesus, G. (2015). Hypothalamic-pituitary-gonadal axis involvement in learning and memory and Alzheimer's disease: more than "just" estrogen. Frontiers in Endocrinology, 6, 45.

Bonelli, R., \& Cummings, J. (2007). Frontal-subcortical circuitry and behavior. Dialogues in clinical neuroscience, 9(2), 141.

Broidy, L., Cauffman, E., Espelage, D., Mazerolle, P., \& Piquero, A. (2003). Sex differences in empathy and its relation to juvenile offending. Violence and victims, 18(5), 503-516.

Buss, D. (1995). Evolutionary Psychology: A new paradigm for psychological sciences. Psychological Enquiry, 6, 1-30.

Buss, D. (2009). The role of emotions in adaptations for exploitation. Behavioral and Brain Sciences, 32(5), 391.

Butler, J. (1990). Gender trouble. Feminism and the Subversion of Identity. New York, NY. Routledge.

Byne, W., Karasic, D., Coleman, E., Eyler, A., Kidd, J., Meyer-Bahlburg, H., ... \& Pula, J. (2018). Gender dysphoria in adults: an overview and primer for psychiatrists. Transgender Health, 3(1), 57-A3.

Cahill, L., Uncapher, M., Kilpatrick, L., Alkire, M., Turner, J. (2004). Sexrelated hemispheric lateralization of amygdala function in emotionally influenced memory: an FMRI investigation. Learn. Mem. 11 (3), 261-266. 
Card, N., Stucky, B., Sawalani, G., \& Little, T. (2008). Direct and indirect aggression during childhood and adolescence: A meta-analytic review of gender differences, intercorrelations, and relations to maladjustment. Child development, 79(5), 1185-1229.

Carothers, B., \& Reiss, H. (2013). Men and women are from earth: Examining the latent structure of gender. Journal of Personality \& Social Psychology, 104, 2, 385-407. doi: 10 1037/a0030437

Carrier, D., Schilling, N., \& Anders, C. (2015). Muscle activation during maximal effort tasks: evidence of the selective forces that shaped the musculoskeletal system of humans. Biology open, 4(12), 1635-1642.

Champagne, F., \& Curley, J. (2016). Plasticity of the maternal brain across the lifespan. New directions for child and adolescent development, 2016(153), 921.

Chaplin, T. (2015). Gender and emotion expression: A developmental contextual perspective. Emotion Review, 7(1), 14-21.

Chapman, E., Baron-Cohen, S., Auyeung, B., Knickmeyer, R., Taylor, K., \& Hackett, G. (2006). Fetal testosterone and empathy: evidence from the empathy quotient (EQ) and the "reading the mind in the eyes" test. Social Neuroscience, 1(2), 135-148.

Chodorow, N. (1999). The reproduction of mothering: Psychoanalysis and the sociology of gender. University of California Press.

Christov-Moore, L., Simpson, E., Coudé, G., Grigaityte, K., Iacoboni, M., \& Ferrari, P. (2014). Empathy: gender effects in brain and behavior.

Neuroscience \& Biobehavioral Reviews, 46, 604-627.

Cohen-Bendahan, C., Buitelaar, J., Van Goozen, S., Orlebeke, J., \& CohenKettenis, P. (2005). Is there an effect of prenatal testosterone on aggression and other behavioral traits? A study comparing same-sex and opposite-sex twin girls. Hormones and Behavior, 47(2), 230-237.

Cohen, J. (1988). Statistical power analysis for the behavioral sciences (2nd ed.). Hillsdale, NJ: Erlbaum.

Connellan, J., Baron-Cohen, S., Wheelwright, S., Batki, A., \& Ahluwalia, J. (2000). Sex differences in human neonatal social perception. Infant behavior and Development, 23(1), 113-118.

Couse, J., Yates, M., Walker, V., \& Korach, K. S. (2003). Characterization of the hypothalamic-pituitary-gonadal axis in estrogen receptor (ER) null mice reveals hypergonadism and endocrine sex reversal in females lacking ER $\alpha$ but not ER $\beta$. Molecular Endocrinology, 17(6), 1039-1053. 
Crestani, C., Alves, F., Gomes, F., Resstel, L., Correa, F., \& Herman, J. (2013). Mechanisms in the bed nucleus of the stria terminalis involved in control of autonomic and neuroendocrine functions: a review. Current neuropharmacology, 11(2), 141-159.

David, S., Naudet, F., Laude, J., Radua, J., Fusar-Poli, P., Chu, I., ... \& Ioannidis, J. (2018). Potential reporting bias in neuroimaging studies of sex differences. Scientific reports, 8(1), 1-8.

Davidson, L., Vandongen, R., Rouse, I., Beilin, L., \& Tunney, A. (1984). Sexrelated differences in resting and stimulated plasma noradrenaline and adrenaline. Clinical science, 67(3), 347-352.

De Vries, G., \& Södersten, P. (2009). Sex differences in the brain: the relation between structure and function. Hormones and behavior, 55(5), 589-596.

Decety, J., \& Lamm, C. (2006). Human empathy through the lens of social neuroscience. TheScientificWorldJOURNAL, 6, 1146-1163.

Del Giudice, M., Booth, T., \& Irwing, P. (2012). The distance between Mars and Venus: Measuring global sex differences in personality. PloS one, 7(1).

Deng, Y., Chang, L., Yang, M., Huo, M., \& Zhou, R. (2016). Gender differences in emotional response: Inconsistency between experience and expressivity. PloS one, 11(6), e0158666.

Denley, M., Gatford, N., Sellers, K., \& Srivastava, D. (2018). Estradiol and the development of the cerebral cortex: an unexpected role?. Frontiers in neuroscience, 12, 245.

Diamond, M. (2000). Sex and gender: Same or different? Feminism and Psychology, 10(1), 46-54.

Doidge, N. (2008). The brain that changes itself. Melbourne: Scribe.

Eagly, A., \& Wood, W. (2013). The nature-nurture debates: 25 years of challenges in understanding the psychology of gender. Perspectives on Psychological Science, 8(3), 340-357.

El-Kalliny, M., \& Donaldson, Z. (2021). Attached. Retrieved from https://aeon.co/essays/what-do-we-know-about-social-attachment-and-humannature?utm source $=$ Aeon + Newsletter\&utm campaign $=3042 \mathrm{c} 33 \mathrm{f} 53$ EMAIL_CAMPAIGN_2021_07_14_05_40\&utm_medium=email\&utm term $=0 \_411 \mathrm{a} 82 \mathrm{e} 59 \mathrm{~d}-3042 \mathrm{c} 33 \mathrm{f53}-70920655$. Visited July 15, 2021.

Eliot, L., Ahmed, A., Khan, H., \& Patel, J. (2021). Dump the "dimorphism": Comprehensive synthesis of human brain studies reveals few male-female differences beyond size. Neuroscience \& Biobehavioral Reviews. 
Erickson-Schroth, L. (2013). Update on the biology of transgender identity. Journal of Gay \& Lesbian Mental Health, 17(2), 150-174.

Fang, Y., Yamaguchi, T., Song, S., Tritsch, N., \& Lin, D. (2018). A hypothalamic midbrain pathway essential for driving maternal behaviors. Neuron, 98(1), 192-207.

Feldman, M., \& Lindquist, K. (2021) What makes a woman's body? Retrieved from https://aeon.co/essays/womens-bodies-emerge-on-the-shorelinebetween-biology-and-culture?utm_source=Aeon Visited January 23, 2021.

Fernández, R., Delgado-Zayas, E., Ramírez, K., Cortés-Cortés, J., Gómez-Gil, E., Esteva, I., ... \& Pásaro, E. (2020). Analysis of four polymorphisms located at the promoter of the estrogen receptor Alpha ESR1 gene in a population with gender incongruence. Sexual medicine, 8(3), 490-500.

Fernández, R., Guillamon, A., Cortés-Cortés, J., Gómez-Gil, E., Jácome, A., Esteva, I., et al. (2018). Molecular basis of Gender Dysphoria: androgen and estrogen receptor interaction. Psychoneuroendocrinology, 98, 161-167.

Fernández, R., Ramírez, K., Gómez-Gil, E., Cortés-Cortés, J., Mora, M., Aranda, G., ... \& Pásaro, E. (2021). Gender-affirming hormone therapy modifies the $\mathrm{CpG}$ methylation pattern of the ESR1 gene promoter after six months of treatment in transmen. The Journal of Sexual Medicine, 17(9), 1795-1806.

Fiani, C. (2018). Beyond the Binary: Gender Identity and Mental Health Among Transgender and Gender Non-Conforming Adults. CUNY Academic Works.

Fine, C. (2013). Is there neurosexism in functional neuroimaging investigations of sex differences?. Neuroethics, 6(2), 369-409.

Fine, C. (2017). Testosterone rex: unmaking the myths of our gendered minds. Icon Books.

Fine, C. (2020). Sexual Dinosaurs. Retrieved from https://aeon.co/essays/trumped-up-charges-of-feminist-bias-are-bad-forscience. Visited August 6, 2020.

Fine, C., Dupré, J., \& Joel, D. (2017). Sex-linked behavior: evolution, stability, and variability. Trends in cognitive sciences, 21(9), 666-673.

Fine, C., Joel, D., \& Rippon, G. (2019). Eight things you need to know about sex, gender, brains, and behavior: A guide for academics, journalists, parents, gender diversity advocates, social justice warriors, tweeters, Facebookers, and everyone else not otherwise specified. Scholar \& Feminist Online, 15.

Finkel, E. (2012). The Genome Generation. Melbourne Univ. Publishing. 
Frere, P., Vetter, N.., Artiges, E., Filippi, I., Miranda, R., Vulser, H., PaillèreMartinot, M., Ziesch, V., Conrod, P., Cattrell, A., \& Walter, H.. (2020). Sex effects on structural maturation of the limbic system and outcomes on emotional regulation during adolescence. NeuroImage, 210, 116441.

Freud, S. (1966). Project for a scientific psychology (1950 [1895]). In The Standard Edition of the Complete Psychological Works of Sigmund Freud, I (1886-1899): Pre-Psycho-Analytic Publications and Unpublished Drafts, 281-391.

Fuster, J. (2009). Prefrontal Cortex. In Larry Squire (Ed.), Encyclopedia of Neuroscience (pp. 905-908). Academic Press.

García-Acero, M., Moreno-Niño, O., Suárez-Obando, F., Molina, M., Manotas, M., Prieto, J., et al. (2020). Disorders of sex development: Genetic characterization of a patient cohort. Molecular Medicine Reports, 21(1), 97106.

Gilligan, C. (1993). In a different voice. Harvard University Press.

Gliske, S. (2019). A new theory of gender dysphoria incorporating the distress, social behavioral, and body-ownership networks. ENeuro, 6(6).

Goddings, A., Mills, K., Clasen, L., Giedd, J., Viner, R., \& Blakemore, S. (2014). The influence of puberty on subcortical brain development. Neuroimage, 88, 242-251.

Goldstein, J., Seidman, L., Horton, N., Makris, N., Kennedy, D., Caviness Jr., et al. (2001). Normal sexual dimorphism of the adult human brain assessed by in vivo magnetic resonance imaging. Cerebral cortex, 11(6), 490-497.

Gouveia, F., Hamani, C., Fonoff, E., Brentani, H., Alho, E.., De Morais, R., et al. (2019). Amygdala and Hypothalamus: historical overview with focus on aggression. Neurosurgery, 85(1), 11-30.

Grabowska, A. (2017). Sex on the brain: Are gender-dependent structural and functional differences associated with behavior?. Journal of neuroscience research, 95(1-2), 200-212.

Gräff, J., Kim, D., Dobbin, M., \& Tsai, L. (2011). Epigenetic regulation of gene expression in physiological and pathological brain processes. Physiological reviews, 91(2), 603-649.

Green, J., \& Spikins, P. (2020). Not just a virtue: the evolution of selfcontrol. Time and Mind, 1-23.

Greenberg, D, Warrier, V., Allison, C., \& Baron-Cohen, S. (2018). Testing the Empathizing-Systemizing theory of sex differences and the Extreme Male Brain theory of autism in half a million people. Proceedings of the National Academy of Sciences, 115(48), 12152-12157. 
Guillamon, A., Junque, C., \& Gómez-Gil, E. (2016). A review of the status of brain structure research in transsexualism. Archives of Sexual Behavior, 45(7), 1615-1648.

Hahn, A., Kranz, G., Küblböck, M., Kaufmann, U., Ganger, S., Hummer, A., et al. (2015). Structural connectivity networks of transgender people. Cerebral Cortex, 25(10), 3527-3534.

Halpern, D. (2013). Sex differences in cognitive abilities. Psychology press.

Hare, B. (2017). Survival of the friendliest: Homo sapiens evolved via selection for prosociality. Annual review of psychology, 68, 155-186.

Heberlein, A., Padon, A., Gillihan, S., Farah, M., \& Fellows, L. (2008). Ventromedial frontal lobe plays a critical role in facial emotion recognition. Journal of cognitive neuroscience, 20(4), 721-733.

Hermans, E. J., Putman, P., \& Van Honk, J. (2006). Testosterone administration reduces empathetic behavior: A facial mimicry study. Psychoneuroendocrinology, 31(7), 859-866.

Hewitt, J., Paul, C., Kasiannan, P., Grover, S., Newman, L., \& Warne, G. (2012). Hormone treatment of gender identity disorder in a cohort of children and adolescents. Medical Journal of Australia, 196(9), 578-581.

Hines, M. (2011). Gender development and the human brain. Annual review of neuroscience, 34, 69-88.

Hines, M. (2017). Gonadal Hormones and Sexual Differentiation of Human Brain and Behavior. Hormones, Brain, and Behavior, 3(5), 247-278, doi.org/10.1016/B978-0-12-803592-4.00103-6

Hines, M. (2020). Neuroscience and sex/gender: looking back and forward. Journal of Neuroscience, 40(1), 37-43.

Hinojosa-Laborde, C., Chapa, I., Lange, D., \& Haywood, J. (1999). Gender differences in sympathetic nervous system regulation. Clinical and Experimental Pharmacology and Physiology, 26(2), 122-126.

Hoekzema, E., Schagen, S., Kreukels, B., Veltman, D., Cohen-Kettenis, P., Delemarre-van De Waal, H., et al. (2015). Regional volumes and spatial volumetric distribution of gray matter in the gender dysphoric brain. Psychoneuroendocrinology, 55, 59-71.

Huber, R., \& Kravitz, E. (2010). Aggression: towards an integration of gene, brain and behavior. Social behavior: Genes, ecology and evolution, 165-180.

Hyde, J. (2005). The gender similarities hypothesis. American psychologist, 60(6), 581 . 
Hyde, J. (2014). Gender similarities and differences. Annual review of psychology, 65, 373-398.

Hyde, J., Bigler, R., Joel, D., Tate, C., \& Anders, S. (2018). The future of sex and gender in psychology: Five challenges to the gender binary. The American psychologist. incongruence. International Review of Psychiatry, 28(1), 120128.

Joel, D., \& McCarthy, M. (2017). Incorporating sex as a biological variable in neuropsychiatric research: where are we now and where should we be?. Neuropsychopharmacology, 42(2), 379.

Joel, D., Berman, Z., Tavor, I., Wexler, N., Gaber, O., Stein, Y., ... \& Assaf, Y. (2015). Sex beyond the genitalia: The human brain mosaic. Proceedings of the National Academy of Sciences, 112(50), 15468-15473.

Joel, D., Garcia-Falgueras, A., \& Swaab, D. (2020). The complex relationships between sex and the brain. The Neuroscientist, 26(2), 156-169.

Johanson, M., Vaurio, O., Tiihonen, J., \& Lähteenvuo, M. (2020). A systematic literature review of neuroimaging of psychopathic traits. Frontiers in psychiatry, 10, 1027.

Johnson, M., Dismukes, A., Vitacco, M., Breiman, C., Fleury, D., \& Shirtcliff, E. (2014). Psychopathy's influence on the coupling between hypothalamicpituitary-adrenal and-gonadal axes among incarcerated adolescents. Developmental Psychobiology, 56(3), 448-458.

Jones, R., \& Lopez, K. (2014). Human reproductive biology. Chapter Sixteen. Academic Press.

Kaiser, A. (2012). Re-conceptualizing "sex" and "gender" in the human brain. Zeitschrift für Psychologie.

Kelsey, C., Farris, K., \& Grossmann, T. (2021). Variability in Infants' Functional Brain Network Connectivity Is Associated With Differences in

Klein, D., Wan, Y., Kamyab, S., Okuda, H., \& Sokol, R. (1994). Effects of toxic levels of lead on gene regulation in the male axis: increase in messenger ribonucleic acids and intracellular stores of gonadotrophs within the central nervous system. Biology of reproduction, 50(4), 802-811.

Knickmeyer, R., Baron-Cohen, S., Raggatt, P., \& Taylor, K. (2005). Foetal testosterone, social relationships, and restricted interests in children. Journal of child psychology and psychiatry, 46(2), 198-210.

Kolla, N., Boileau, I., Karas, K., Watts, J., Rusjan, P., Houle, S., \& Mizrahi, R. (2021). Lower amygdala fatty acid amide hydrolase in violent offenders with antisocial personality disorder: an [11 C] CURB positron emission tomography study. Translational psychiatry, 11(1), 1-11. 
Kret, M., \& De Gelder, B. (2012). A review on sex differences in processing emotional signals. Neuropsychologia, 50(7), 1211-1221.

Kreukels, B., \& Guillamon, A. (2016). Neuroimaging studies in people with gender incongruence. International Review of Psychiatry, 28(1), 120-128.

Kristensen, T., Christensen, L., Frystyk, J., Glintborg, D., T'sjoen, G., Roessler, K., \& Andersen, M. (2021). Effects of testosterone therapy on constructs related to aggression in transgender men: A systematic review. Hormones and behavior, 128, 104912.

Kruijver, F., Zhou, J., Pool, C., Hofman, M., Gooren, L., \& Swaab, D. (2000). Male-to-female transsexuals have female neuron numbers in a limbic nucleus. The Journal of Clinical Endocrinology \& Metabolism, 85(5), 20342041.

Kuiri-Hänninen, T., Sankilampi, U., \& Dunkel, L. (2014). Activation of the hypothalamic-pituitary-gonadal axis in infancy: minipuberty. Hormone research in paediatrics, 82(2), 73-80.

Kung, K. Li, G., Golding, J., \& Hines, M. (2018). Preschool gender-typed play behavior at age 3.5 years predicts physical aggression at age 13 years. Archives of sexual behavior, 47(4), 905-914.

Legato, M. (2018). Untangling the Gordian Knot of Human Sexuality: What Is the Biologic Basis of Variations in Sexual Phenotype?. Gender and the Genome, 2(3), 62-67.

Leinbach, M., \& Fagot, B. (1986). Acquisition of gender labels: A test for toddlers. Sex Roles, 15(11-12), 655-666.

Leinung, M., \& Joseph, J. (2020). Changing Demographics in Transgender Individuals Seeking Hormonal Therapy: Are Trans Women More Common Than Trans Men?. Transgender Health, 5(4), 241-245.

Lenschow, C., \& Lima, S. (2020). In the mood for sex: Neural circuits for reproduction. Current Opinion in Neurobiology, 60, 155-168.

Li, Q., Xiao, M., Song, S., Huang, Y., Chen, X., Liu, Y., \& Chen, H. (2020). The personality dispositions and resting-state neural correlates associated with aggressive children. Social cognitive and affective neuroscience, 15(9), 10041016.

Ligthart, L., Bartels, M., Hoekstra, R., Hudziak, J., \& Boomsma, D. (2005). Genetic contributions to subtypes of aggression. Twin Research and Human Genetics, 8(5), 483-491.

LoBue, V., DeLoache, J. (2009). On the detection of emotional facial expressions: Are girls really better than boys?. Behavioral and Brain Sciences, 32(5), 397 
Lonstein, J., Pereira, M., Marler, C., \& Morrell, J. (2014). Parental behavior. Knobil and Neill's Physiology of Reproduction, 4th edition Elsevier, New York, 2371-2438.

Loomes, R., Hull, L., \& Mandy, W. (2017). What is the male-to-female ratio in autism spectrum disorder? A systematic review and meta-analysis. Journal of the American Academy of Child \& Adolescent Psychiatry, 56(6), 466-474.

López, M., Pol, H., Franke, B., \& Klein, M. (2020). Localizing genomic regions contributing to the extremes of externalizing behavior: ADHD, aggressive and antisocial behaviors. bioRxiv, 750091.

Lotze, M., Domin, M., Gerlach, F., Gaser, C., Lueders, E., Schmidt, C., et al. (2019). Novel findings from 2,838 adult brains on sex differences in gray matter brain volume. Scientific reports, 9(1), 1-7.

Low, B. (2015). Why sex matters: A Darwinian look at human behaviour. Princeton University Press.

Lutchmaya, S., Baron-Cohen, S., \& Raggatt, P. (2002). Foetal testosterone and eye contact in 12-month-old human infants. Infant Behavior and Development, 25(3), 327-335.

Manzouri, A., Kosidou, K., \& Savic, I. (2017). Anatomical and functional findings in female-to-male transsexuals: testing a new hypothesis. Cerebral

Marsh, R., Gerber, A., \& Peterson, B. (2008). Neuroimaging studies of normal brain development and their relevance for understanding childhood neuropsychiatric disorders. Journal of the American Academy of Child \& Adolescent Psychiatry, 47(11), 1233-1251.

Marwha, D., Halari, M., \& Eliot, L. (2017). Meta-analysis reveals a lack of sexual dimorphism in human amygdala volume. Neuroimage, 147, 282-294.

McCarthy, M., \& Arnold, A. (2011). Reframing sexual differentiation of the brain. Nature neuroscience, 14(6), 677.

McCarthy, M., \& Konkle, A. (2005). When is a sex difference not a sex difference?. Frontiers in neuroendocrinology, 26(2), 85-102.

McCarthy, M., Arnold, A., Ball, G., Blaustein, J., \& De Vries, J. (2012). Sex differences in the brain: the not so inconvenient truth. Journal of Neuroscience, 32(7), 2241-2247

McCarthy, M., De Vries, G., \& Forger, N. (2017). Sexual differentiation of the brain: a fresh look at mode, mechanisms, and meaning. Hormones, Brain and Behavior (Third Edition), 5, 3-32. doi: 10.1016/B978-0-12-803592-4.00091-2

McClure, E., Monk, C., Nelson, E., Zarahn, E., Leibenluft, E., Bilder, R., et al. (2004). A developmental examination of gender differences in brain 
engagement during evaluation of threat. Biological psychiatry, 55(11), 10471055 .

McDonald, M., James, R., \& Roberto, D. (2021). True Crime Consumption as Defensive Vigilance: Psychological Mechanisms of a Rape Avoidance System. Archives of Sexual Behavior, 1-24.

McDonald, P. (2012). Workplace sexual harassment 30 years on: A review of the literature. International Journal of Management Reviews, 14(1), 1-17.

McEwen, B. (2001). Invited review: Estrogens effects on the brain: multiple sites and molecular mechanisms. Journal of applied physiology, 91(6), 27852801.

McFadden, J. (2020). Integrating information in the brain's EM field: the cemi field theory of consciousness. Neuroscience of consciousness, (1), niaa016.

McFadden, J. (2021). Brain Wifi. Retrieved from https://aeon.co/essays/doesconsciousness-come-from-the-brains-electromagnetic-

field?utm source $=$ Aeon + Newsletter\&utm campaign $=3 \mathrm{f} 36 \mathrm{f} 37 \mathrm{e} 06-$ EMAIL_CAMPAIGN 2021_04_08 04 54\&utm_medium=email\&utm term $=0$ 411a82e59d-3f36f37e06-70920655. Visited April 10, 2021.

Meyer-Bahlburg, H. (2019). "Diagnosing" Gender? Categorizing GenderIdentity Variants in the Anthropocene. Archives of sexual behavior, 1-9.

Mishra, G., Chung, H., Cano, A., Chedraui, P., Goulis, D., Lopes, P., ... \& Lambrinoudaki, I. (2019). EMAS position statement: Predictors of premature and early natural menopause. Maturitas, 123, 82-88.

Montanez, A. (2017) Beyond XX and XY: The Extraordinary Complexity of Sex Determination. Scientific American.

https://www.scientificamerican.com/article/beyond-xx-and-xy-theextraordinary-complexity-of-sex-determination/ Visited 20 March, 2021

Mueller, S., Landré, L., Wierckx, K., \& T'Sjoen, G. (2017). A structural magnetic resonance imaging study in transgender persons on cross-sex hormone therapy. Neuroendocrinology, 105(2), 123-130.

Negri-Cesi, P., Colciago, A., Celotti, F., \& Motta, M. (2004). Sexual differentiation of the brain: role of testosterone and its active metabolites. Journal of endocrinological investigation, 27, 120-127.

Nergaard, K. (2019). Empathic expressions among three-year-olds in play and interaction in ECEC institutions in Norway: Bodily empathic expressions purposed for peers' well-being and confirming relationships. Early Child Development and Care, 189(9), 1444-1456.

Nguyen, H., Chavez, A., Lipner, E., Hantsoo, L., Kornfield, S., Davies, R., \& Epperson, C. (2018). Gender-affirming hormone use in transgender 
individuals: impact on behavioral health and cognition. Current psychiatry reports, 20(12), 1-9.

Numan, M., \& Insel, T. (2006). The neurobiology of parental behavior (Vol. 1). Springer Science \& Business Media.

O'Hanlan, K., Gordon, J., \& Sullivan, M. (2018). Biological origins of sexual orientation and gender identity: Impact on health. Gynecologic oncology, 149(1), 33-42.

Olson, K., \& Gülgöz, S. (2018). Early findings from the transyouth project: Gender development in transgender children. Child Development Perspectives, 12(2), 93-97.

Orobio de Castro, B., Merk, W., Koops, W., Veerman, J. W., \& Bosch, J. D. (2005). Emotions in social information processing and their relations with reactive and proactive aggression in referred aggressive boys. Journal of Clinical Child and Adolescent Psychology, 34(1), 105-116.

Owen-Blakemore, J., Berenbaum, S., \& Liben, L. (2009). Gender development. New York: Psychology Press.

Pallayova, M., Brandeburova, A., \& Tokarova, D. (2019). Update on Sexual Dimorphism in Brain Structure-Function Interrelationships: A Literature Review. Applied Psychophysiology and Biofeedback, 44(4), 271-284.

Parker, G. (2021). How Soon Hath Time... A History of Two "Seminal" Publications. Cells, 10(287), https://doi.org/10.3390/cells10020287.

Parkins, R. (2012). Gender and emotional expressiveness: An analysis of prosodic features in emotional expression. Griffith University.

Paulus, M., Wörle, M., \& Christner, N. (2020). The emergence of human altruism: Preschool children develop a norm for empathy-based comforting. Journal of Cognition and Development, 21(1), 104-124.

Pavlova, M. (2017). Sex and gender affect the social brain: beyond simplicity. Journal of Neuroscience Research, 95(1-2), 235-250.

Pearson, R., Lightman, S., \& Evans, J. (2009). Emotional sensitivity for motherhood: late pregnancy is associated with enhanced accuracy to encode emotional faces. Hormones and Behavior, 56(5), 557-563.

Pejić, S., Todorović, A., Stojiljković, V., Pavlović, I., Gavrilović, L., Popović, N., et al. (2015). Antioxidant status and sex hormones in women with simple endometrial hyperplasia. Basic Principles and Clinical Significance of Oxidative Stress. Gowder SJT (ed.). InTech, Rijeka, 243-79.

Pfaff, D. (2011). Man and woman: An inside story. New York: Oxford. 
Rametti, G., Carrillo, B., Gomez-Gil, E., Junque, C., Zubiarre-Elorza, L., Segovia, S., et al. (2011). The microstructure of white matter in male to female transsexuals before cross-sex hormonal treatment. A DTI study. Journal of Psychiatric Research 45, 949-954.

Ratnu, V., Emami, M., \& Bredy, T. (2017). Genetic and epigenetic factors underlying sex differences in the regulation of gene expression in the brain. Journal of neuroscience research, 95(1-2), 301-310.

Raz, G., Jacob, Y., Gonen, T., Winetraub, Y., Flash, T., Soreq, E., \& Hendler, T. (2014). Cry for her or cry with her: context-dependent dissociation of two modes of cinematic empathy reflected in network cohesion dynamics. Social cognitive and affective neuroscience, 9(1), 30-38.

Reber, J., \& Tranel, D. (2017). Sex differences in the functional lateralization of emotion and decision making in the human brain. Journal of neuroscience research, 95(1-2), 270-278.

Rice, W., Friberg, U., \& Gavrilets, S. (2012). Homosexuality as a consequence of epigenetically canalized sexual development. The Quarterly review of biology, 87(4), 343-368.

Rippon, G. (2017). Culture not biology is behind many differences between the sexes. New Scientist. https://www. newscientist. com/article/2144424culture-not-biology-is-behind-many-differences-between-the-sexes.

Rippon, G. (2019). The Gendered Brain: The new neuroscience that shatters the myth of the female brain. Random House. Kindle Edition.

Rippon, G., Jordan-Young, R., Kaiser, A., \& Fine, C. (2014).

Recommendations for sex/gender neuroimaging research: key principles and implications for research design, analysis, and interpretation. Frontiers in human neuroscience, $8,650$.

Ristori, J., Cocchetti, C., Romani, A., Mazzoli, F., Vignozzi, L., Maggi, M., et al. (2020). Brain Sex Differences Related to Gender Identity Development: Genes or Hormones?. International Journal of Molecular Sciences, 21(6), 2123.

Ritchie, S., Cox, S., Shen, X., Lombardo, M., Reus, L., Alloza, C., et al. (2018). Sex differences in the adult human brain: evidence from 5216 UK biobank participants. Cerebral Cortex, 28(8), 2959-2975.

Roselli, C. (2018). Neurobiology of gender identity and sexual orientation. Journal of neuroendocrinology, 30(7), e12562.

Roth, K. (2015). LGBT: Moving towards equality. Online Article.

January, 23, P1. http://reports.weforum.org/outlook-globalagenda-2015/wpcontent/blogs.dir/59/mp/files/pages/files/lgbt.pdf Visited January 23, 2021. 
Roxo, M., Franceschini, P., Zubaran, C., Kleber, F.., \& Sander, J. (2011). The limbic system conception and its historical evolution. The scientific world journal, 11, 2427-2440.

Ruble D, Taylor L, Cyphers L, Greulich F, Lurye L, Shrout P. (2007) The role of gender constancy in early gender development. Child Development 78(4):1121-1136

Ruiz-Cortes, Z. (2012) Gonadal Sex Steroids: Production, Action and Interactions in Mammals. In: Sergej Ostojic (Eds.), Steroids -From Physiology to Clinical Medicine. https://doi.org/10.5772/52994

Rutherford, A. (2018). A Brief History of Everyone Who Ever Lived: The Human Story Retold Through Our Genes. The Experiment.

Sakata, J., \& Crews, D. (2004). Developmental sculpting of social phenotype and plasticity. Neuroscience \& Biobehavioral Reviews, 28(2), 95-112.

Saketopoulou, A. (2014). Mourning the body as bedrock: Developmental considerations in treating transsexual patients analytically. Journal of the American Psychoanalytic Association, 62(5), 773-806.

Salk, R., Hyde, J., \& Abramson, L. (2017). Gender differences in depression in representative national samples: Meta-analyses of diagnoses and symptoms. Psychological bulletin, 143(8), 783.

Saltzman, W., \& Maestripieri, D. (2011). The neuroendocrinology of primate maternal behavior. Progress in Neuro-Psychopharmacology and Biological Psychiatry, 35(5), 1192-1204.

Sánchez, F., \& Vilain, E. (2013). Transgender identities: Research and controversies. In C. J. Patterson \& A. R. D'Augelli (Eds.), Handbook of psychology and sexual orientation (p. 42-54). Oxford University Press.

Sanchis-Segura, C., Ibañez-Gual, M.., Adrián-Ventura, J., Aguirre, N., Gómez-Cruz, Á., Avila, C., \& Forn, C. (2019). Sex differences in gray matter volume: how many and how large are they really?. Biology of sex

Differences, 10(1), 1-19.

Sato, T., Matsumoto, T., Kawano, H., Watanabe, T., Uematsu, Y., Sekine, K., et al. (2004). Brain masculinization requires androgen receptor function. Proceedings of the National Academy of Sciences, 101(6), 16731678.

Savin-Williams, R. (2016). Sexual orientation: Categories or continuum? Commentary on Bailey et al.(2016). Psychological Science in the Public Interest, 17(2), 37-44. 
Schieman, S., \& Van Gundy, K. (2000). The personal and social links between age and self-reported empathy. Social Psychology Quarterly, Vol. 63, No. 2, 152-174.

Schulte-Rüther, M., Markowitsch, H., Shah, N.., Fink, G., \& Piefke, M. (2008). Gender differences in brain networks supporting empathy. Neuroimage, 42(1), 393-403.

Serano, J. (2016). Whipping Girl: A Transsexual Woman on Sexism and the Scapegoating of Femininity. Berkley, Seal Press.

Siegal, M., \& Bergman, A. (2002). Waddington's canalization revisited: developmental stability and evolution. Proceedings of the National Academy of Sciences, 99(16), 10528-10532.

Simerly, R. (2002). Wired for reproduction: organization and development of sexually dimorphic circuits in the mammalian forebrain. Annual review of neuroscience, 25(1), 507-536

Simerly, R. (2010). Sexual Differentiation of the Central Nervous System. In G. Lemke, (Ed.). Developmental neurobiology. Academic Press.

Sindermann, C., Cooper, A., \& Montag, C. (2019). Empathy, Autistic Tendencies, and Systemizing Tendencies - Relationships Between Standard Self-Report Measures. Frontiers in psychiatry, 10, 307.

Singer, T., \& Klimecki, O. (2014). Empathy and compassion. Current Biology, 24(18), R875-R878.

Sisk, C. (2016). Hormone-dependent adolescent organization of socio-sexual behaviors in mammals. Current opinion in neurobiology, 38, 63-68.

Smith, E., Junger, J., Derntl, B., \& Habel, U. (2015). The transsexual brain-A review of findings on the neural basis of transsexualism. Neuroscience \& Biobehavioral Reviews, 59, 251-266.

Smith, M., Deady, D., Moore, F., Jones, B., Cornwell, R., Stirrat, M., et al. (2012). Maternal tendencies in women are associated with estrogen levels and facial femininity. Hormones and Behavior, 61(1), 12-16.

Sokolowski, K., \& Corbin, J. (2012). Wired for behaviors: from development to function of innate limbic system circuitry. Frontiers in molecular neuroscience, 5, 55.

Stam, D., Huang, Y., \& Van den Stock, J. (2019). Non-overlapping and Inverse Associations Between the Sexes in Structural Brain-Trait Associations. Frontiers in psychology, 10, 904.

Stanley, E. (2019). Widen the window: Training your brain and body to thrive during stress and recover from trauma. Avery. 
Steensma, T., Biemond, R., de Boer, F., \& Cohen-Kettenis, P. (2011). Desisting and persisting gender dysphoria after childhood: a qualitative follow-up study. Clinical child psychology and psychiatry, 16(4), 499-516.

Stevens, J., \& Hamann, S. (2012). Sex differences in brain activation to emotional stimuli: a meta-analysis of neuroimaging studies. Neuropsychologia, 50(7), 1578-1593.

Strauss, P., Cook, A., Winter, S., Watson, V., Wright Toussaint, D., Lin, A. (2017). Trans Pathways: the mental health experiences and care pathways of trans young people. Summary of results. Telethon Kids Institute, Perth, Australia.

Stuijfzand, S., De Wied, M., Kempes, M., Van de Graaff, J., Branje, S., \& Meeus, W. (2016). Gender differences in empathic sadness towards persons of the same-versus other-sex during adolescence. Sex roles, 75(9), 434-446.

Sunstein, C. (2020). The triumph of the friendly: A review of Brian Hare and Vanessa Woods, survival of the friendliest. Journal of Bioeconomics, 1-5.

Swaab, D. (2004). Sexual differentiation of the human brain: relevance for gender identity, transsexualism and sexual orientation. Gynecological Endocrinology, 19(6), 301-312.

Swaab, D., \& Garcia-Falgueras, (2009). Sexual differentiation of the human brain in relation to gender identity and sexual orientation. Functional Neurology, 24(1), 17.

Swain, J., Lorberbaum, J., Kose, S., \& Strathearn, L. (2007). Brain basis of early parent-infant interactions: psychology, physiology, and in vivo functional neuroimaging studies. Journal of child psychology and psychiatry, 48(3-4), 262-287.

Sweatt, J., Nestler, E., Meaney, M., \& Akbarian, S. (2013). An overview of the molecular basis of epigenetics. In: J. Sweatt, M. Meaney, \& E. Nestler (Eds.), Epigenetic regulation in the nervous system: Basic mechanisms and clinical impact. Academic Press. doi: 10 1016/B978-0-12-391494-1 00001-X

Tasopoulos, C. (2018). Human Sexual Differentiation and Aberration Spectrum. Encephalos, 55, 25-29.

Tay, P., Ting, Y., \& Tan, K. (2019). Sex and Care: The evolutionary psychological explanations for sex differences in formal care occupations. Frontiers in psychology, 10, 867.

Taylor, S., Klein, L., Lewis, B., Gruenewald, T., Gurung, R., \& Updegraff, J. (2000). Biobehavioral responses to stress in females: tend-and-befriend, not fight-or-flight. Psychological review, 107(3), 411. 
Temple-Newhook, J., Pyne, J., Winters, K., Feder, S., Holmes, C., Tosh, J., et al. (2018). A critical commentary on follow-up studies and "desistance" theories about transgender and gender-nonconforming children. International Journal of Transgenderism, 19(2), pp.212-224.

Theisen, J., Sundaram, V., Filchak, M., Chorich, L., Sullivan, M., Knight, J., et al. (2019). The use of whole exome sequencing in a cohort of transgender individuals to identify rare genetic variants. Scientific Reports, 9(1), 1-11.

Thurer, S. (2005). The end of gender: A psychological autopsy. Routledge.

Toufexis, D., Rivarola, M., Lara, H., \& Viau, V. (2014). Stress and the reproductive axis. Journal of neuroendocrinology, 26(9), 573-586.

Tozzi, A., Durante, V., Manca, P., Di Mauro, M., Blasi, J., Grassi, S., et al. (2019). Bidirectional synaptic plasticity is driven by sex neurosteroids targeting estrogen and androgen receptors in hippocampal CA1 pyramidal neurons. Frontiers in Cellular Neuroscience, 13, 534.

Tunç, B., Solmaz, B., Parker, D., Satterthwaite, T., Elliott, M., Calkins, M., et al. (2016). Establishing a link between sex-related differences in the structural connectome and behavior. Philosophical Transactions of the Royal Society B: Biological Sciences, 371(1688), 20150111.

Unger, E., Burke Jr, K., Yang, C., Bender, K., Fuller, P., \& Shah, N. (2015). Medial amygdala aromatase neurons regulate aggression in both sexes. Cell reports, 10(4), 453-462.

Unger, R. (1979). Toward a redefinition of sex and gender. American Psychologist, 34(11), 1085.

Uribe, C., Junque, C., Gómez-Gil, E., Abos, A., Mueller, S., \& Guillamon, A. (2020). Brain network interactions in transgender individuals with gender incongruence. Neuroimage, 211, 116613.

van Anders, S. (2015). Beyond sexual orientation: Integrating gender/sex and diverse sexualities via sexual configurations theory. Archives of Sexual Behavior, 1-37.

van der Dennen, J. (2005). Introduction to The Nature of the Sexes. In The Nature of the Sexes: The Sociobiology of Sex Differences and the 'Battle of the Sexes'.

Vance, S., Ehrensaft, D., \& Rosenthal, S. (2014). Psychological and medical care of gender nonconforming youth. Pediatrics, 134(6), 1184-1192.

Verma, R., Balhara, Y., \& Gupta, C. (2011). Gender differences in stress response: Role of developmental and biological determinants. Industrial psychiatry journal, 20(1), 4. 
Vigil, J. (2009). A socio-relational framework of sex differences in the expression of emotion. Behavioral and Brain Sciences, 32(5), 375.

Vogt, G. (2017). Facilitation of environmental adaptation and evolution by epigenetic phenotype variation: insights from clonal, invasive, polyploid, and domesticated animals. Environmental Epigenetics, 3(1).

von Polier, G., Greimel, E., Konrad, K., Großheinrich, N., Kohls, G., Vloet, T., ... \& Schulte-Rüther, M. (2020). Neural correlates of empathy in boys with early onset conduct disorder. Frontiers in psychiatry, 11, 178.

Watson, J. (1972). Smiling, cooing, and "the game". Merrill-Palmer Quarterly of Behavior and Development, 18(4), 323-339.

Weigel, N., Vodolaga, V., Shapoval, G., Kartashova, E., \& Safronenko, A. (2020). Modern Androgyny as a Manifestation of a Universal Personality. Journal of Talent Development and Excellence, 12(3s), 234-241.

West, C., \& Zimmerman, D. (2009). Accounting for doing gender. Gender \& society, 23(1), 112-122.

Wheelock, M., Hect, J.., Hernandez-Andrade, E., Hassan, S., Romero, R., Eggebrecht, A., \& Thomason, M. (2019). Sex differences in functional connectivity during fetal brain development. Developmental cognitive neuroscience, 36, 100632.

Wierckx, K., Van Caenegem, E., Schreiner, T., Haraldsen, I., Fisher, A., Toye, K., ... \& T'Sjoen, G. (2014). Cross-sex hormone therapy in trans persons is safe and effective at short-time follow-up: results from the European network for the investigation of gender incongruence. The journal of sexual medicine, 11(8), 1999-2011.

Wierman, M. (2007). Sex steroid effects at target tissues: mechanisms of action. Advances in physiology education, 31(1), 26-33.

Wizemann, T., \& Pardue, M. (2001). Exploring the biological contributions to human health: does sex matter? Committee on understanding the biology of sex and gender differences. Board on Health Sciences Policy, Institute of Medicine. Retrieved from http://www.nap.edu/catalog/10028.html. Visited August 21, 2020.

Wong, L., Wang, L., D’amour, J., Yumita, T., Chen, G., Yamaguchi, T., et al. (2016). Effective modulation of male aggression through lateral septum to medial hypothalamus projection. Current biology, 26(5), 593-604.

Wynn, R., Høiseth, M., \& Pettersen, G. (2012). Psychopathy in women: theoretical and clinical perspectives. International journal of women's health, 4, 257. 
Yang, L., Comninos, A., \& Dhillo, W. (2018). Intrinsic links among sex, emotion, and reproduction. Cellular and molecular life sciences, 75(12), $2197-$ 2210 .

Yang, Y., Joshi, S., Jahanshad, N., Thompson, P., \& Baker, L. (2017). Neural correlates of proactive and reactive aggression in adolescent twins. Aggressive behavior, 43(3), 230-240.

Zaidi, Z. (2010). Gender differences in human brain: a review. The open anatomy journal, 2(1).

Zell, E., Krizan, Z., \& Teeter, S. (2015). Evaluating gender similarities and differences using metasynthesis. American Psychologist, 70(1), 10.

Zietsch, B., Morley, K., Shekar, S., Verweij, K., Keller, M., Macgregor, S., et al (2008). Genetic factors predisposing to homosexuality may increase mating success in heterosexuals. Evolution and Human Behavior, 29(6), 424-433.

Zucker, K. (2018). The myth of persistence: Response to "A critical commentary on follow-up studies and 'desistance' theories about transgender and gender non-conforming children" by Temple-Newhook et al. (2018). International Journal of Transgenderism, 19(2), 231-245.

Zucker, K., Bradley, S. J., \& Sanikhani, M. (1997). Sex differences in referral rates of children with gender identity disorder: Some hypotheses. Journal of Abnormal Child Psychology, 25(3), 217-227.

Zuloaga, D., Jordan, C., Breedlove, S., \& Squire, L. (2009). Sexual differentiation of the brain. Developmental neurobiology, 348.

Zwickl, S., Wong, A., Dowers, E., Leemaqz, S.., Bretherton, I., Cook, T., ... \& Cheung, A. S. (2021). Factors associated with suicide attempts among Australian transgender adults. BMC psychiatry, 21(1), 1-9. 